\title{
PENGARUH BUDAYA ORGANISASI DAN LINGKUNGAN KERJA TERHADAP KINERJA PEGAWAI PDAM TIRTA MUSI UNIT SEBERANG ULU 2 PALEMBANG
}

\author{
Martini \\ Dosen tetap Fakultas Ekonomi \\ Universitas Palembang
}

\begin{abstract}
ABSTRAK
Penelitian ini bertujuan untuk mengetahui pengaruh budaya organisas dan lingkungan kerja terhadap kinerja karyawan PDAM Tirta Musi Unit Seberang Ulu 2 Palembang. Jenis penelitian ini adalah penelitian asosiatif kausal. Model analisis yang digunakan yaitu Analisis Regresi Linear Berganda. Sampel dalam penelitian ini adalah 36 responden yang merupakan kinerja karyawan PDAM Tirta Musi Unit Seberang Ulu 2 Palembang.

Permasalahan dalam penelitian ini adalah “ apakah dan berpengaruh secara parsial dan simultan terhadap kinerja?" Pengujian hipotesis menggunakan analisis regresi linear berganda, melalui uji $T$ dan uji $F$, dengan maksud untuk mengetahui pengaruh variabel independen terhadap variabel dependent pada tingkat kepercayaan $95 \%(a=0,05)$.

Hasil penguji pada uji $T$ pada variabel budaya organisasi berpengaruh positif terhadap kinerja, hal terlihat dari nilai $t$ hitung (3,318) $>t$ tabel (2,035), signifikansi $(0,00)$ di bawah atau lebih kecil dari 0,05, sedangkan pada variabel lingkungan kerja berpengaruh positif terhadap kinerja, hal terlihat dari nilai $t$ hitung $(4,167)>t$ tabel $(2,035)$ dan signifikansi $(0,00)$ di bawah atau lebih kecil dari 0,05 . Pada pengujian pada uji $F$ pada variabel budaya organisasi dan lingkungan kerja berpengaruh positif terhadap kinerja, hal terlihat dari nilai $F$ hitung (14,694) > F tabel (3,285), dan signifikansi $(0,01)$ di bawah atau lebih kecil dari 0, 05.
\end{abstract}

\section{Kata Kunci : Budaya Organisasi Lingkungan Kerja \& Kinerja}

\section{PENDAHULUAN}

\subsection{Latar Belakang}

Pengelolaan sumber daya manusia tidak lepas dari faktor pegawai yang diharapkan dapat berprestasi sebaik mungkin demi mencapai tujuan organisasi pemerintah. Pegawai merupakan asset utam aorganisasi dan mempunyai peran yang strategis didalam organisasi yaitu sebagai pemikir, perencana, dan pengendali aktivitas organisasi. Demi tercapainya tujuan organisasi, karyawan memerlukan motivasi untuk bekerja lebih rajin. Melihat pentingnya karyawan dalam organisasi, maka karyawan diperlukan perhatian lebih serius terhadap tugas yang dikerjakan sehingga tujuan organisasi tercapai. Sumber daya manusia merupakan bagian penggerak dari perusahaan yang memiliki potensi berkembang dan secara aktif mendorong produktifitas dalam memenuhi tujuan perusahaan. Mengelola karyawan tidak hanya sekedar memberi diskripsi pekerjaan dan peraturan yang harus dipatuhi saja, tetapi perlu adanya hubungan yang sinergis antara perusahaan dengan karyawan untuk mencapai tujuan perusahaan bersama. Edwin B.Flippo (2015:67 menjelaskan manajemen sumber daya manusia adalah perencanaan, pengorganisasian, pengarahan dan pengawasan kegiatan- kegiatan pengadaan ,pengembangan, pemberian kompensasi, pengintegrasian, pemeliharaan dan pelepasan sumberdaya manusia agar tercapai berbagai tujuan individu, organisasi dan masyarakat. Untuk mencapai hubungan yang sinergis tersebut, perusahaan harus dapat memperhatikan pola kinerja pegawainya. Dengan diadakannya riset sumber daya manusia (karyawan) secara intens diharapkanperusahaan mendapat umpan balikguna perbaikankinerja perusahaan. 
Berdirinya PDAM Tirta Musi Palembang merupakan peninggalan zaman Belanda, dimana pembentukan PDAM Tirta Musi Palembang sebagai Badan Usaha Milik Daerah (BUMD).Berdasarkan keputusanWalikotamadyaKepala Daerah Tingkat IIPalembangNo.30 Tahun 1995 tentang susunan organisasi, tata kerja jenjang pangkat dan jabatan PDAM Tirta Musi Palembang, tugas pokok Perusahaan Daerah adalah mengelola air minum dan sarana air di daerah,untuk meningkatkan kesejahteraan masyarakat yang mencakup aspek sosial ekonomi, kesehatan dan pelayanan umum. Faktor yang mempengaruhi kinerja adalah budaya organisasi. Budaya organisasi merupakan satu wujud anggapan yang dimiliki, diterima secara implisit oleh kelompok dan menentukan bagaimana kelompok tersebut rasakan, pikirkan dan bereaksi terhadap lingkungannya yang beraneka ragam (Djokosantoso, 2015:18) . Hal ini bermakna, bahwa budaya organisasi diberikan kepada pegawai baru melalui proses sosialisasi, budaya organisasi mempengaruhi pegawai di tempat kerja serta budaya organisasi berlaku pada dua tingkatan yang berbeda. Masing-masing tingkat bervariasi dalam kaitannya dengan pandangan keluar dan kemampuan bertahan terhadap perubahan.Dengan demikian budaya organisasi mempunyai peranan penting dalam menentukan perubahan organisasi di mana organisasi dapat tumbuh dan berkembang karena budaya organisasi yang terdapat di dalamnya mampu merangsang semangat kerja pegawai di dalam organisasi sehingga dapat meningkatkan kinerjanya .Faktor lingkungan kerja merupakan faktor yang sangat penting sebagai kondisi atau keadaan tempat yang mempengaruhi kinerja karyawaan. Lingkungan kerja merupakan bagian yang penting dalam perusahaan, meskipun lingkungan kerja tidak melaksanakan proses produksi dalam suatu perusahaan, namun lingkungan kerja mempunyai pengaruh langsung terhadap kinerja para karyawan.Menurut Sedarmayanti (2015:102) lingkungan kerja terbagi menjadi dua yaitu lingkungan kerja fisik dan lingkungan kerja non fisik.Lingkungan kerja fisik diantaranya adalah penerangan, temperatur, kelembaban, sirkulasi udara, kebisingan, getaran mekanis, bau tidak sedap, tata warna, dekorasi, musik, dan keamanan di tempat kerja. Sedangkan lingkungan kerja non fisik diantaranya adalah hubungan sosial di tempat kerja baik antara atasan dengan bawahan atau hubungan antara bawahan. Menurut Nitisemito (2015:79) faktor-faktor yang termasuk lingkungan kerja adalah pewarnaan, kebersihan, pertukaran udara, penerangan, musik, kebisingan, ruang gerak, dan hubungan antara karyawan atau karyawan dengan atasan. Lingkungan kerja sangat berpengaruh terhadap kinerja seseorang, lingkungan yang sesuai dapat memberikan kesannyaman dan berfungsi sebagai sarana yang harus diperhatikan terhadap efektivitas dan efisensi kerja, sedangkan lingkungan kerja yang tidak baik dapat mengakibatkan terjadinya kecelakaan diunit-unit produksi yang pada akhirnya secara keseluruhan akan menurunkan tingkat produktivitas perusahaan. Berdasarkan fenomena-fenomena yang telah dijelaskan diatas, maka peneliti mengambil judul "Pengaruh Budaya Organisasi Dan Lingkungan Kerja Terhadap Kinerja Pegawai PDAM Tirta Musi Unit Seberang Ulu 2 Palembang”.

\subsection{Perumusan masalah}

Berdasarkan latar belakang yang telah dikemukan diatas, maka perumusan permasalahan penelitian ini adalah :

a. Apakah budaya organisasi dan lingkungan kerja berpengaruh secara parsial terhadap kinerja pegawai PDAM Tirta Musi Unit Seberang Ulu 2 Palembang?

b. Apakah budaya organisasi dan lingkungan kerja berpengaruh secara simultan terhadap kinerja pegawai PDAM Tirta Musi Unit Seberang Ulu 2Palembang?

\subsection{Tujuan Penelitian}

Adapun tujuan penelitian ini adalah :

a. Untuk mengetahui pengaruh budaya organisasi dan lingkungan kerja berpengaruh secara parsial terhadap 
kinerja pegawai PDAM Tirta Musi Unit Seberang Ulu 2 Palembang

b. Untuk mengetahui pengaruh budaya organisasi dan lingkungan kerja berpengaruh secara simultan terhadap kinerja pegawai PDAM Tirta Musi Unit Seberang Ulu 2 Palembang.

\section{TINJAUAN PUSTAKA}

\subsection{Landasan Teori}

A. Budaya Organisasi

1. Pengertian Budaya Organisasi

Suatu keberhasilan kerja, berakar pada nilai-nilai yang dimiliki dan perilaku yang menjadi kebiasaannya.Nilai-nilai tersebut bermula dari adat kebiasaan, agama, norma dan kaidah yang menjadi keyakinannya menjadi kebiasaan dalam perilaku kerja atau organisasi.Nilainilaiyang telah menjadi kebiasaan tersebut dinamakan budaya.Oleh karena budaya dikaitkan dengan mutu atau kualitaskerja, maka dinamakan budaya kerja (Widagdho, 2012:76)

\section{Edy Sutrisno}

mendefinisikan budaya sebagai perangka tsistem nilai-nilai (values),keyakinan-

keyakinan(beliefs), asumsi-

asumsi(assumptions), atau norma-norma yang telah lama berlaku, disepakati sandi ikuti oleh para anggota suatu organisasi sebagai pedoman perilaku dan pemecahan masalah- masalah organisasinya. Budaya organisasi juga disebut budaya perusahaan, yaitu seperangkat nilai- nilai atau norma- norma yang telah relatif lama berlakunya, dianut bersama oleh para anggota organisasi (karyawan )sebagai norma perilaku dalam menyelesaikan masalah-masalah organisasi (perusahaan). Sementara menurut Mas'ud (2012:47) Budaya organisasional adalah sistem makna,nilai-nilai dan kepercayaan yang dianut bersama dalam suatuorganisasi yang menjadi rujukan untuk bertindak dan membedakan organisasi satu dengan organisasi lain. Budaya organisasi menjadi identitas atau karakter utama organisasi yang dipeliharadan dipertahankan. Mas'ud juga menyatakan bahwa suatu budaya yang kuat merupakan perangkat yang bermanfaat untuk mengarahkan perilaku, karena membantu karyawan untuk melakukan pekerjaan yang lebih baik sehingga setiap karyawan pada awal karirnya perlu memahami budaya dan bagaimana budaya tersebut terimplementasikan.

Soehardi Sigit (2015:261-262) mengungkapkan dan menerangkan bahwa budaya organisasi dikatakan kuat, jika nilai-nilai budaya itu disadari, dipahami dan diikuti,serta dilaksanakan oleh sebagian besar para anggota organisasi. Adapun tanda-tanda bahwa suatu budaya itu kuat adalah sebagai berikut:

1. Nilai-nilai budaya saling menjalin, tersosialisasikan dan menginternalisasi pada para anggota.

2. Perilaku anggota (karyawan) terkendalikan dan terkoordinasikan oleh kekuatan yang tak tampak(invisible) atau informal.

3. Para anggota (karyawan )merasacommitted dan loyal pada organisasi.

4. Ada partisipasi para karyawan pada organisasi.

5. Semua kegiatan berorientasi pada misi dan tujuan.

6. Ada 'shared meaning' atau kebersamaan mengenai sesuatu yang dipandang berarti bagi para karyawan.

7. Para anggota karyawan tahu apa yang harus di lakukan dan yang tidak boleh dilakukan.

8. Ada perasaan rewarding pada anggota (karyawan), karena diakui dan dihargai martabat dan kontribusinya.

9. Budaya yang berlaku sesuai dengan strategi dan menopang tujuan organisasi.

\section{Indikator Budaya Organisasi}

Budaya perusahaan merupakan sesuatu hal yang sangat kompleks. Untuk itu,di dalam pengukuran budaya perusahaan atau organisasi diperlukan indikator yang merupakan karakteristik dasar buday aorganisasi sebagai wujud nyata keberadaanya.Berikut adalah indikator budaya organisasi yang dikemukakan oleh Robbins \& Coulter dalam Ardana (2015:167):

1. Inovasi dan pengambilan resiko, 
yaitu kadar seberapa jauh

karyawan didorong untuk inovatif dan mengambil resiko.

2. Perhatian kehal yang rinci atau detail, yaitu kadar seberapa jauh karyawan diharapkan mampu menunjukkan ketepatan, analisis dan perhatian yang rinci/detail.

3. Orientasi hasil, yaitu kadar seberapa jauh pimpinan berfokus pada hasil atau output dan bukannya pada cara mencapai hasil itu.

4 . Orientasi orang, yaitu kadar seberapa jauh keputusan manajemen turut mempengaruhi orang-orang yang ada dalam organisasi.

5 .Orientasi tim, yaitu kadar seberapa jauh pekerjaan disusun berdasarkan tim dan bukannya perorangan.

6. Keagresifan, yaitu kadar seberapa jauh karyawan agresif dan bersaing, bukannya dari pada bekerja sama.

7. Kemantapan/stabilitas, yaitu kadar seberapa jauh keputusan dan tindakan organisasi menekankan usaha untuk mempertahankan statusquo

\section{Fungsi Budaya Organisasi}

Sebagai pedoman untuk
mengontrol perilaku anggota
organisasi, budaya organsiasi memiliki
manfaat danfungsi yang berguna
bagiorganisasi. Dari sisi fungsi, budaya
organisasi mempunyai beberapa fungsi.
Fungsi budaya organisasi menurut
Robbins
adalah sebagai berikut:

1. Budaya menciptakan pembedaan yang jelas antara satu organisasi dan yang lain.

2. Budaya membawa suatu rasa identitas bagi anggotaanggotaorganisasi.

3. Budaya mempermudah timbulnya komitmen pada sesuatu yang lebih luas dari pada kepentingan diri individual seseorang.

4. Budaya merupakan perekat sosial yang membantu mempersatukan organisasi itu dengan memberikan standar- standar yang tepat untuk dilakukanolehkaryawan.

5. Budaya sebagaimekanisme pembuat makna dan kendali yang memandu dan membentuk sikap serta perilaku karyawan.

Sedangkan menurut Sunarto (2012:26), budaya o rganisasi mempunyai beberapa fungsi antara lain:

1. Budaya organisasi berfungsi sebagai pengikat seluruh komponen organisasi, terutama pada saat organisasi menghadapi guncangan baik dari dalam maupun dari luar akiba tadanya perubahan

2. Budaya organisasi merupakan alat untuk menyatukan beragam sifat, karakter, bakat dan kemampuan yang ada didalam organisasi.

3. Budaya organisasi merupakan salah satu identitas organisasi, artinya perusahaan memiliki identitas sebagai perusahaan yang mengutamakan ketepatan dan kecepatan.

4. Budaya organisasi berfungsi sebagai suntikan energi untuk mencapai kinerja yang tinggi.

5. Budaya organisasi merupakan representasi dari ciri kualitas yang berlaku dalam organisasi tersebut.

6. Budaya organisasi merupakan pemberi semangat bagi para anggota organisasi. Organsiasi yang kuat akan menjadi motivator yang kuat juga bagi para anggotanya.

7. Adanya perubahan didalamsuatuorganisasi

akanmembawa pandangan barutentang kepemimpinan. Seorang pemimpin akandikatakan berhasil apabila dapat membawa anggotanya keluar dari krisis akibat perubahan yangterjadi. Keberhasilan pemimpin disebabkan karenaiamemiliki visi danmisiyangkuat.

8. Salah satu fungsi budaya organisasi adalah untuk meningkatkan nilai dari stakeholdernya,yaitu anggota organisasi, pelanggan, pemasokdan pihak pihak lain yang berhubungan dengan organisasi. 


\section{B. Lingkungan Kerja \\ 1. Pengertian Lingkungan Kerja}

Lingkungan kerja merupakan salah satu faktor penting dalam menciptakan kinerja karyawan. Karena lingkungan kerja mempunyai pengaruh langsung terhadap karyawan didalam menyelesaikan pekerjaanyang pada akhirnya akan meningkatkan semangat kerja. Suatu kondisi lingkungan kerja dikatakan baik apa bila karyawan dapat melaksanakan kegiatan secara optimal, sehat, aman, dan nyaman. Oleh karena itu penentuan danpenciptaan lingkungan kerja yang baik akan sangat menentukan keberhasilan pencapaian tujuan organisasi. Sebaliknya apa bila lingkungan kerja yang tidak baik akan dapat menurunkan motivasi serta semangat kerja dan akhirnya dapat menurunkan kinerja karyawan. Kondisi dan suasana lingkungan kerja yang baik akan dapat tercipta dengan adanya penyusunan organisasi secara baik dan benar sebagaimana yang dikatakan oleh Sarwoto( 2013:86) bahwa suasana kerja yang baik dihasilkan terutama dalam organisasi yang tersusun secara baik, sedangkan suasana kerja yang kurang baik banyak ditimbulkan oleh organisasi yang tidak tersusun dengan baik pula.Dari pendapat tersebut dapat diterangkan bahwa terciptanya suasana kerja sangat dipengaruhi oleh struktur organisasi yang ada dalam organisasi tersebut.

Menurut Sedarmayanti ( 2015:102 ) menyatakan bahwa secara garis besar, jenis lingkungan kerja terbagimenjadi 2 yaitu:

1. Lingkungan Kerja Fisik

Lingkungan kerja fisik adalah semua keadaan berbentuk fisik yang terdapat di sekitar tempat kerja yang dapat mempengaruhi karyawan baik secara langsung maupun secara tidak langsung. Menurut Komarudin (2013:87) lingkungan kerjafisik adalah keseluruhan atau setiap aspek dari gejala fisik dan sosialkulturalyangmengelilingi atau mempengaruhi individu. lain halnya menurut Alex S. Nitisemito (2012:80) Lingkungan kerja fisik adalah segala sesuatu yang ada disekita rpara pekerja yang dapat mempengaruhi dirinya dalam menjalankan tugas-tugas yang dibebankan, misalnya penerangan, suhu udara, ruang gerak, keamanan,kebersihan, musik dan lain-lain..

Faktor-faktor lingkungan kerja fisika dalah sebaga iberikut:
1. Pewarnaan
2. Penerangan
3. Udara
4. Suarabising
5. Ruang Gerak
6.Keamanan
7.Kebersihan

\section{Lingkungan Kerja Non Fisik}

Lingkungan kerja non fisik adalah semua keadaan yang terjadi yang berkaitan dengan hubungsn kerja, baik hubungan dengan atasan maupun hubungan dengan bawahan sesamarekan kerja, ataupun hubungan dengan bawahan ( Sedamayanti, 2015:103). Lingkungan kerja non fisik ini tidak kalah pentingnya dengan lingkungan kerja fisik. Semangat kerja karyawan sangat dipengaruhi oleh keadaan lingkungan kerja non fisik,misalnya hubungan dengan sesama karyawan dan dengan pemimpinnya. Apabila hubungan seorang karyawan dengan karyawan lain dan dengan pimpinan berjalan dengan sangat baik maka akan dapat membuat karyawan merasa lebih nyaman berada di lingkungan kerjanya.Dengan begitu semangat kerja karyawan akan meningkat dan kinerja pun juga akan ikut meningkat. Ada 5 aspek lingkungan kerja non fisik yang bisa mempengaruhi perilaku karyawan, yaitu:

1. Struktur kerja, yaitu sejauh mana bahwa pekerjaan yang diberikan kepadanya memiliki struktur kerja dan organisasi yang baik.

2. Tanggung jawab kerja, yaitu sejauh mana pekerja merasakan bahwa pekerjaan mengerti tanggung jawab mereka serta bertanggung jawab atas tindakan 
mereka.

3. Perhatian dan dukungan pemimpin, yaitu sejauh mana karyawan merasakanbahwa pimpinan sering memberikan pengarahan, keyakinan, perhatian serta menghargai mereka.

4. Kerjasamaantar kelompok, yaitu sejauh mana karyawa nmerasakan ada kerjasama yang baik diantara kelompok kerja yang ada.

5. Kelancaran komunikasi, yaitu sejauh mana karyawan merasakan adanya komunikasi yang baik, terbuka, dan lancar, baik antara teman sekerja ataupun dengan pimpinan.

\section{Faktor-faktor Yang Mempengaruhi Lingkungan Kerja}

Lingkungan kerja adalah kekuatan yang mendorong semangat yang ada didalam maupu ndiluar dirinya baik itu yang berupa reward maupun punishment sehingga Herberg dalam Luthans(2012:84) menyatakan bahwa pada manusia terdapat enam faktor pemuas.

1) prestasi kerja yang diraih (achievement).

2). pengakuan orang lain(recognition).

3). tanggung jawab (responsibility).

4). peluang untukmaju (advancement).

5). Kepuasan kerja itu sendiri (the workitself).

6). Dan pengembangan karir (the possibility of growth).

Sedangkan faktor pemeliharaan (maintenance factor). Yang disebut dengan disatisfier atau extrinsic lingkungan kerja yang meliputi:

1).KondisiKerja;

2).Keamanandankeselamatankerja;

3).Kondisikerja;

4).Status;

5).Prosedurperusahaan;

6).Mutudarisupervisetekhnisdarihubun gan antarateman sejawat, atasan, dan bawahan.

\section{Kinerja}

\section{Pengertian Kinerja}

Kinerja merupakan suatu fungsi dari motivasi dan kemampuan. Untuk menyelesaikan tugas atau pekerjaan seseorang sepatutnya memiliki derajat kesediaan dan tingkat kemampuan tertentu. Kinerja merupakan suatu fungsi dari motivasi dan kemampuan untuk menyelesaikan tugas atau pekerjaan seseorang sepatutnya memiliki derajat kesediaan dan tingkat kemampuan tertentu, (Rivai, 2012:548). Menurut Hadari Nawawi (2012:234) kinerja dimaksudkan adalah hasil pelaksanaan suatu pekerjaan baik yang bersifat fisik/material maupun non-fisik/non material dalam melaksanakan tugas-tugasnya.

MenurutT. Hani Handoko(2012;2122)adaenammetode penilaian kerjak aryawan:

1. Ratingscale (ukuran penilaian).

2. Checklist (daftar pemeriksaan)

3. Critical incident method (metode peristiwa kritis)

4. Field review method (metode peninjauan lapangan),

5. Tesdanobservasi prestasi kerja,

6. Methodranking (metode urut),

\section{Manfaatpenilaiankinerja}

Menurut T. Hani Handoko (2012:34-35) manfaat penilaian kinerja :

1. Perbaikan prestasi kerja atau kinerja.

2. Penyesuaian-penyesuaian kompensasi.

3. Keputusan-keputusan penempatan.

4. Perencanaan dan pengembangan karir.

5. Mendeteksi penyimpangan proses staffing.

6.Melihat ketidak akuratan informasional.

7. Mendeteksi kesalahan-kesalahan desain pekerjaan.

8. Melihat tantangan-tantangan eksternal.

\section{Faktor-Faktor Yang Mempengaruhi Kinerja}

Para pimpinan organisasi sangat menyadari adanya perbedaan kinerja antara satu karyawan dengan karyawan, lainnya yang berada di bawah pengawasannya. Walaupun karyawan-karyawan bekerja pada tempat yang sama namun produktifitas mereka tidaklah sama.Secara garis besar perbedaan kinerja ini disebabkan oleh dua faktor, (As'ad, 
2012:49),yaitu: faktor individu dan situasi kerja.

Menurut James L. Gibson(dalam Srimulyo 2012:39), ada tiga perangkat variabel yang mempenganruhi perilaku dan prestasi kerja atau kinerja,yaitu:

1.Variabel individual,

2.Variabel organisasional

3.Variabel psikologis

Sedangkan menurut Malayu S.P.
Hasibuan (2012:56) terdapat beberapa faktor yang mempengaruhi dalam pencapaian kinerja pegawai yaitu :
a. Kuantitas Kerja
$\begin{array}{llr}\text { bualitas } & \text { Kerja Merupakan } \\ \text { pencapaian } & \text { pekerjaan yang }\end{array}$ dihasilkan.
c. Disiplin Kerja
d. Kerjasama

\subsection{Penelitian Sebelumnya}

Tabel 2.1

Penelitian Sebelumnya

\begin{tabular}{|c|c|c|}
\hline No & Nama, tahun, judul, & Hasil \\
\hline 1. & $\begin{array}{l}\text { Pengaruh LingkunganKerja, } \\
\text { Budaya Organisasi, Dan } \\
\text { Kepemimpinan Terhadap Kinerja } \\
\text { Pegawai Pada Dinas Pasar Kota } \\
\text { Semarang } \\
\text { Sumber: } \\
\text { Journal Of Management, } \\
\text { Volume2 No.2 Maret } 20162016\end{array}$ & $\begin{array}{l}\text { Berdasarkan hasil pengujian terhadap variabel } \\
\text { lingkungan kerja terhadap kinerja Pegawai } \\
\text { PadaDinasPasarKotaSemarang } \\
\text { berpengaruh signifikan berdasarkan hasil uji t } \\
\text { dimana nilai thitung sebesar } 4,16 \text { sedangkan nilai } t \\
\text { tabel 2,316. Sedangkan hasil pengujian terhadap } \\
\text { variabel budaya organisasi terhadap kinerja } \\
\text { Pegawai PadaDinasPasarKotaSemarang bahwa } \\
\text { berpengaruh signifikan berdasarkan hasil uji t } \\
\text { dimana nilai thitung sebesar 6,216 sedangkan nilai } \\
\mathrm{t} \text { tabel sebesar 3,415. }\end{array}$ \\
\hline 2 & 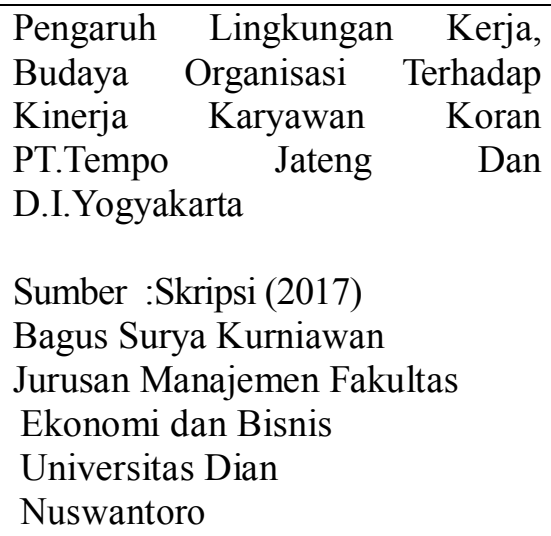 & $\begin{array}{l}\text { Nilai uji t antara lingkungan kerja terhadap kinerja } \\
\text { karyawan sebesar } 2,345 \text {, dengansig. } 0,023 \text {.Nilai } \\
\text { sig.lebihkecil }(<) \text { dari } \alpha=0,05 \text { menunjukkan } \\
\text { diterimanya hipotesis yang menyatakan } \\
\text { lingkungan kerja berpengaruh positif dans } \\
\text { ignifikan terhadap kinerjak aryawan. } \\
\text { Nilaiuji t antara budaya organisasi terhadap } \\
\text { kinerja karyawan sebesar } 2,728 \text { dengans } \\
\text { ig.0,008.Nilai sig.lebih kecil }(<) \text { dari } \alpha=0,05 \\
\text { menunjukkan diterimanya hipotesis yang } \\
\text { menyatakan budaya organisasi berpengaruh } \\
\text { positif dansignifikan terhadap kinerja karyawan. }\end{array}$ \\
\hline
\end{tabular}


Gambar 1

Kerangka Fikir

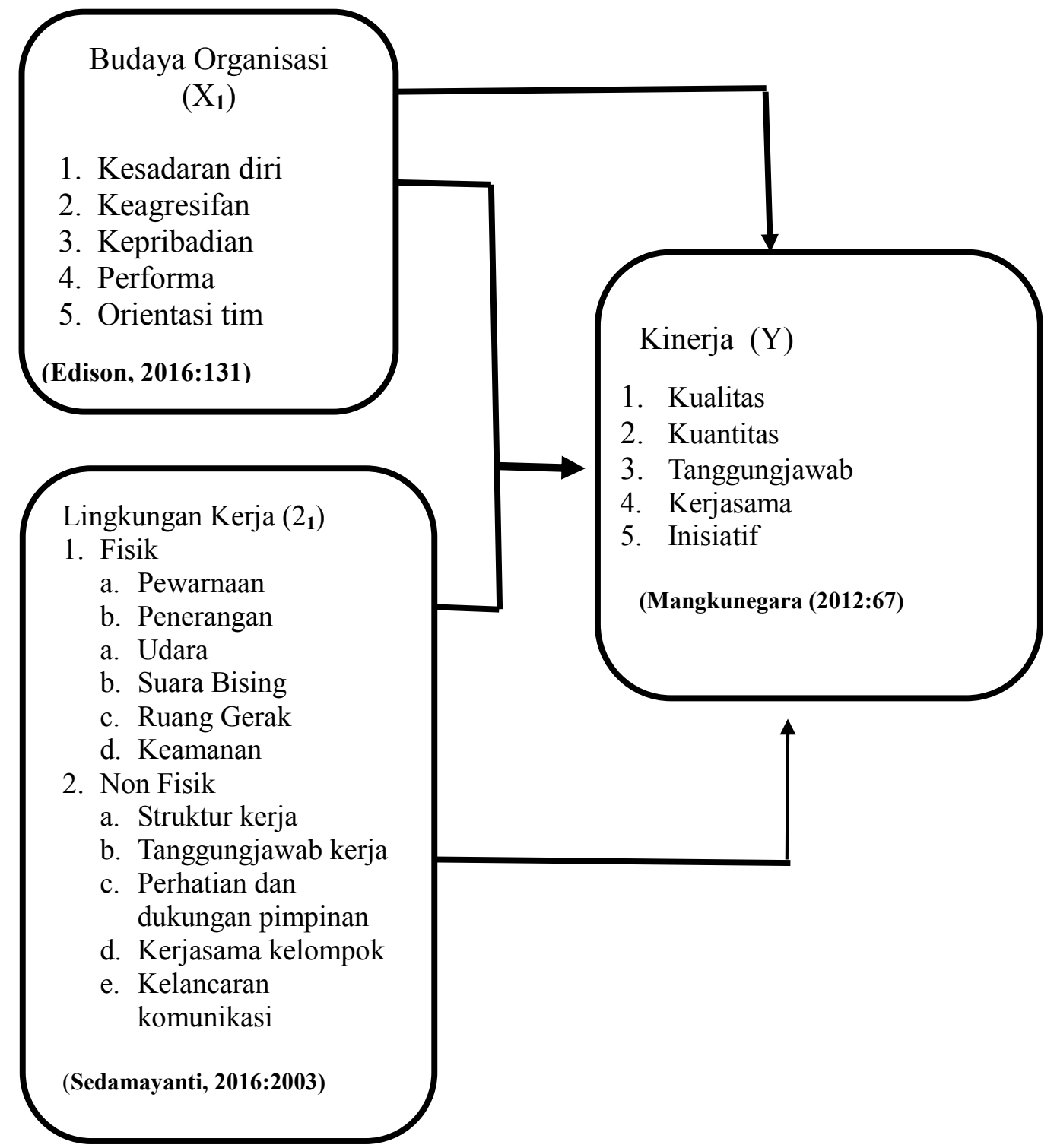

\subsection{Hipotesis Penelitian}

Hipotesis dalam penelitian ini adalah sebagai berikut :

$\mathrm{H}_{0}$ : Tidak ada pengaruh budaya organisasi dan lingkungan kerja secara parsial terhadap kinerja pegawai PDAM Tirta Musi Unit Seberang Ulu 2 Palembang.

$\mathrm{H}_{1}$ : Ada pengaruh budaya organisasi dan lingkungan kerja secara parsial terhadap kinerja pegawai PDAM Tirta Musi Unit Seberang Ulu 2 Palembang

$\mathrm{H}_{0}$ : Tidak ada pengaruh budaya organisasi dan lingkungan kerja secara simultan terhadap kinerja pegawai PDAM Tirta Musi Unit Seberang Ulu 2 Palembang.

$\mathrm{H}_{1}$ : Ada pengaruh budaya organisasi dan lingkungan kerja secara simultan terhadap kinerja pegawai PDAM Tirta Musi Unit Seberang Ulu 2 Palembang. 
III. METODE PENELITIAN

\section{A. Objek Penelitian}

Objek penelitian yaitu kantor PDAM Tirta Musi Unit Seberang Ulu 2 Palembang yang beralamat di Jalan Jenderal Ahmad Yani Plaju Palembang

\section{B. Ruang Lingkup penelitian}

Agar penelitian ini terarah dan tidak menyimpang dari permasalahan maka ruang lingkup penelitian ini adalah masalah budaya organisasi dan lingkungan kerja pengaruhnya terhadap kinerja.

\section{Desain Penelitian}

Desain penelitian yang digunakan penulis adalah desain asosiatif klausal.Menuru tSugiyono (2012:14), desaina sosiatif berguna untuk menganalisis hubungan antara satu variabel dengan variabel lainnya atau bagaimana suatu variabel mempengaruhi variabel lain. Dengan penelitian ini maka akan teori yang dapat berfungsi untuk menjelaskan, meramalkan, dan mengontrol suatu gejala.Data yangd iperoleh dalam penelitian ini akan diolah, dianalisis, dan diproses lebih lanjut dengan dasar teori yang diperoleh selama masa perkuliahan dan tinjauan pustaka. Metode penelitian dirancang melalui langkah-langkah penelitian dari operasional variabel, ,metode pengumpulan data dan diakhiri dengan rancangan pengujian hipotesis dan statistik.

\section{Jenis dan Sumber Data}

eskriptif Jenis penelitian ini adalah Bungin(2012:102) penelitian deskriptif kuantitatif adalah penelitian yang menggambarkan, menjelaskan, atau meringkaskan berbagai kondisi, situasi, fenomena menurut kejadian sebagaimana adanya dan dijelaskan dengan angka-angka. Penelitian ini menggunakan dua jenis sumber data yaitu :

a. Data primer

Data primer yaitu data yang diperoleh langsung melalui wawancara dengan pihak responden khususnya dengan menggunakan quesioner dan mengajukan sejumlah pertanyaan sesuai dengan indikator yang akan diteliti dan hal lain yang mendukung isi penelitian ini.

b. Data sekunder

Data Sekunder yaitu teknik pengumpulan data yang bersumber dari dokumen-dokumen yang berkaitan dengan permasalahan dan pembahasan dalam penelitian ini.

\section{E. Populasi dan sampel}

\section{Populasi}

Menurut Puspowarsito, (2008:92)

populasi adalah keseluruhan objek (orang, kejadian, atau sesuatu) yang mempunyai karakteristik tertentu baik yang kongkrit (tangible) maupun objek yang abstrak (untangible). Anwar (2012:77) mengemukakan tentang populasi adalah sebagai kelompok subjek yang dikenai generalisasi hasil penelitian. Pada penelitian ini yang dijadikan objek penelitian adalah pegawai PDAM Tirta Musi Unit Seberang Ulu 2 Palembang yang berjumlah 36karyawan.

\section{Sampel}

Teknik pengambilan sampel adalah menggunakan teknik jenuh yaitu semua anggota polulasi dijadikan sampel (Anwar Sanusi, 2012:78). Jadi seluruh pegawai PDAM Tirta Musi Unit Seberang Ulu 2 Palembang dijadikan sampel penelitian yaitu sebanyak 36 karyawan.

\section{G. Teknik Analisis Data}

\section{UjiAsumsiKlasik}

Uji asumsi klasik (Dwi Priyanto, 2013:30) adalah pengujian pada variabel penelitian dengan model regresi, apakah dalam variabel dan model regresinya terjadi kesalahan.Untuk mendapatkan model regresi yang baik harus terbebas dari penyimpangan data yang terdiri dari multikolonieritas, heteroskedastisitas dan normalitas. Berikutini macam-macam uji asumsi klasik:

a. Uji Normalitas

Uji normalitas data dilakukan untuk melihat tingkat kenormalan data yang digunakan,apakah data berdistribus inormal atau tidak. Tingkat kenormalan data sangat penting, karena dengan data yang 
terdistribusi normal,maka data tersebut dianggap dapat mewakili populasi.Cara mendeteksinya adalah dengan melihat penyebaran data pada sumber diagonal pada grafik normal P-Pploto fRegression Standardized Residual sebagai dasar pengambilan keputusannya,jikamenyebar sekitar garis dan mengikutigaris diagonal maka residual pada model regresi tersebut terdistribusi secara normal. Jika dari hasil grafik dapat diketahui bahwa titik-titik menyebar sekitar garis dan mengikuti garis diagonal, maka residual pada model regresi terdistribusi secara normal.

b. Uji Multikolinearitas

Ujimultikolinearitas merupakan bentuk pengujian untuk asumsi dalam analisis regresi berganda. Asumsi multikolinearitas menyatakan bahwa variabel independen harus terbebas dari gejala multikolinearitas. Gejala multikolinearitas adalah gejala korelasi antar variabel independen. Gejala ini ditunjukkan dengan korelasi yang ignifikan antar variabel independen. Metode yang digunakan untuk mendeteksi adanya multikolinearitas, dalamp enelitian ini dengan menggunakan tolerance dan VIF (variance inflation factor).Tolerance mengukur variabilitas variabel bebas yang terpilih dan tidak dijelaskan oleh variabel bebas lainnya.Jadi nilai tolerance yang rendah sama dengan nilai VIF (karena VIF = 1/tolerance) dan menunjukkan adanya kolonieritas yang tinggi. Nilai cutoff yang dipakai oleh nilai tolerance 0,10 atau sama dengan nilai nilai VIF diatas10.Apabilaterdapatvariabelbeba smemiliki nilaitolerancelebihdari 0,10 dan nilai VIF kurang dari 10 , makad apat disimpulkan bahwa tidak ada multikolonieritas antar variabel bebas dalam model regresinya.

c. Uji Heteroskedastisitas

Salah satu asumsi padaf ungsi regresi adalah apabila variasi faktor pengganggu selalu sama pada data pengamatan yang satu dengan data pengamatan yang lain. Jika ciri ini dipenuhi, berarti variasi faktor pengganggu pada kelompok data tersebut bersifat homoskedastis. Jika asumsi tersebut tidak dapat dipenuhi maka dapat dikatakan terjadi penyimpangan. Uji heteroskedastisitas bertujuan menguji apakah dalam model regresi terjadi ketidak samaan varian dari residual data yang ada.Model regresi yang baik adalah yang tidak mengalami gejala heteroskedastisitas.Pengujian heteroskedastisitas dalam penelitian ini menggunakan teknik Scatterplot sebagai berikut. Mode lregresi yang baik adalah homoskedastisitas atau tidak terjadi heterokedastisitas. Salah satu cara untuk mendeteksi ada tidaknya heteroskedastisitas adalah dengan melihat grafik plot (ZPRED) dengan residualnya (SRESID).Apabila pada grafik scatter plot tidak ada pola yang jelas, sertatitik-titik menyebar diatas dan dibawah angka 0 pada sumbu Y, maka dapat disimpulkan bahwa tidak terjadi heteroskedastisitas pada model regresi.

\section{Analisis Deskriptif Data}

Analisis deskriptif adalah cara merumuskan dan menafsirkan data yang ada sehingga memberikan gambaran yang jelas mengenai data yang akan diteliti (Sanusi, 2011:67) yaitu :

a. Deskriptif responden

Yang menggambarkan keadaan responden berdasarkan usia, jenis kelamin, dan jenjang pendidikan

b Deskriptif variabel penelitian

Memberikan gambaran mengenai variabel yang akan diteliti tentang lingkungan kerja, budaya organisasi serta pengaruhnya terhadap kinerja. Analisis deskriptif dilakukan peneliti yaitu dengan mendistribusikan jawaban responden dalam bentuk tabel sehingga memperoleh gambaran yang jelas tentang distribusi jawaban 
responden terhadap variabel penelitian.

\section{Uji Instrumen Data}

\section{a. Uji Validitas}

Uji Validitas dan reliabilitas dilakukan untuk menguji apakah angket (kuesioner) yang disebarkan layak untuk dijadikan instrumen penelitian. Uji validitas dan reliabilitas dilakukan pada responden yang lain diluar sampel penelitian yang pada penelitian ini. . Hal ini dilakukan agar data-data yang diperoleh valid dan reliabel. Instrumen yang valid berarti angket yang digunakan untuk mengumpulkan data itu valid. Valid berarti instrumen tersebut dapat digunakan untuk mengukur apa yang hendak diukur, sedangkan instrumen yang reliabel berarti instrumen yang bila digunakan beberapa kali untuk mengukur obyek yang sama, akan menghasilkan data yang sama. (Sugiyono, 2015 : 172). Suatu skala pengukur dikatakan valid apabila skala tersebut digunakan untuk mengukur apa yang seharusnya diukur.

1. Jika $r_{\text {hitung }}>r_{\text {tabel }}$, maka pertanyaan dinyatakan valid

2. Jika $\mathrm{r}_{\text {hitung }}<\mathrm{r}_{\text {tabel, }}$, maka pertanyaan dinyatakan tidak valid

\section{b. Uji Reliabilitas}

Pengujian reliabilitas data dilakukan untuk mengetahui sejauh mana suatu pengukur dapat menunjukkan akurasi dan konsistensi butir pertanyaan. Untuk menguji reliabilitas data digunakan pengukur Cronbach Alpha. Menurut Sugiyono (2015:458) bahwa, "Cronbach Alpha merupakan salah satu koefisien reliabilitas yang paling sering digunakan". Skala pengukuran yang reliabel sebaiknya memiliki nilai Cronbach Alpha minimal 0,60 .

\section{Analisis Deskriptif Statistik}

a. Koefesien Diterminasi

Untuk mengetahui seberapa besar kemampuan variabel independen menjelaskan variabel dependen. Semakin besar nilai koefisien determinasi, maka semakin baik kemampuan variabelbebas menerangkan variabelterikat. Jika determinasi $\left(\mathrm{R}^{2}\right)$ semakinbesar atau mendekati satu,maka dapat dikatakan bahwa variabel bebas semakin besar menjelaskan variabel terikat. Koefisien determinasi $\left(\mathrm{R}^{2}\right)$ pada intinya mengukur seberapa jauh kemampuan model dalam menerangkan variasi variabel dependen. Nilai koefisien determinasi adalah antara nol dan satu. Nilai $R^{2}=$ yang kecil berarti kemampuan variabel-variabel independen dalam menjelaskan variasi variabel dependen amat terbatas.

\section{b. Uji Regresi Berganda}

Untuk mengetahui pengaruh atau hubungan variabel bebas dan variabel tidak bebas dengan menggunakan metode regresi berganda (Multiply Regression).

Rumusnya adalah sebagai berikut:

$$
\mathbf{Y}=\mathbf{a}+\mathbf{b}_{1} \mathbf{X}_{1}+\mathbf{b}_{2} \mathbf{X}_{2}+\mathbf{e}
$$

$$
\begin{array}{ll}
\mathrm{Y} & =\text { Kinerja } \\
a & =\text { Konstanta } \\
b_{1}, b_{2} & =\text { Koefesien regresi } \\
X_{1} & =\text { Budaya Organisasi } \\
X_{2} & =\text { Lingkungan Kerja }
\end{array}
$$

c. Uji t

Uji - $\mathrm{t}$ hitung dua arah bertujuan untuk melihat secara parsial bagaimana pengaruh variabel budaya organisasi $\left(\mathrm{X}_{1}\right)$ atau lingkungan kerja $\left(\mathrm{X}_{2}\right)$ terhadap variabel kinerja (Y). Model hipotesis yang digunakan dalam uji t hitung dua arah ini adalah :

Nilai t hitung dapat diperoleh dengan menggunakan bantuan aplikasi software SPSS 24,0 for Windows. Nilai t hitung selanjutnya akan dibandingkan dengan nilai t tabel dengan tingkat kesalahan $(\alpha=5 \%)$ dan derajat kebebasan $(\mathrm{df})=(\mathrm{n}-\mathrm{k})$. Kriteria pengambilan keputusan yang digunakan adalah :

$\mathrm{H}_{0}$ diterima bila $\mathrm{t}_{\text {hitung }}<\mathrm{t}$ tabel pada $\alpha=5 \%$

$\mathrm{H}_{1}$ diterima bila $\mathrm{t}_{\text {hitung }}>\mathrm{t}_{\text {tabel }}$ pada $\alpha=5 \%$

\section{d. Uji F}

Uji - F hitung dilakukan untuk melihat secara bersama-sama bagaimana pengaruh variabel budaya organisasi $\left(\mathrm{X}_{1}\right)$ dan lingkungan kerja $\left(\mathrm{X}_{2}\right)$ terhadap kinerja (Y). Model hipotesis yang digunakan dalam uji $\mathrm{F}_{\text {hitung }}$ ini adalah:

$\mathrm{H}_{0}: \mathrm{b}_{1}, \mathrm{~b}_{2}=0$ (budaya organisasi dan lingkungan kerja secara bersama-sama tidak 
berpengaruh terhadap kinerja)

$\mathrm{H}_{1}: \mathrm{b}_{1}, \mathrm{~b}_{2} \neq 0$ (budaya organisasi dan lingkungan kerja secara bersama-sama berpengaruh terhadap kinerja)
Nilai F hitung dapat diperoleh dengan menggunakan bantuan aplikasi software SPSS 24.0 for Windows. Selanjutnya nilai F hitung akan dibandingkan dengan nilai $\mathrm{F}$ Tabel dengan kriteria kesalahan $(\alpha=5 \%)$ dan derajat kebebasan (df) $=(\mathrm{n}-\mathrm{k}),(\mathrm{k}-2)$

IV. HASIL PENELITIAN DAN PEMBAHASAN

C. Analisis Deskriptif Responden

1. Deskriptif responden berdasarkan usia

Tabel 4.1

Karakteristik Responden Berdasarkan Usia

\begin{tabular}{|c|c|c|}
\hline Usia & $\begin{array}{c}\text { Jumlah Responden } \\
\text { (orang) }\end{array}$ & $\begin{array}{c}\text { Persentase } \\
(\%)\end{array}$ \\
\hline $25-35$ tahun & 8 & 22,22 \\
\hline $36-45$ tahun & 10 & 27,78 \\
\hline$<46$ tahun & 18 & 50 \\
\hline Jumlah & 36 & 100 \\
\hline
\end{tabular}

Sumber: Hasil Penelitian (Data diolah, 2021)

Pada Tabel 4.1 dapat dilihat bahwa usia antara 25-35 tahun sebanyak orang responden atau 22,22\%, usia 36-45 tahun sebanyak 10 responden atau 27,78\% dan usia 46 tahun keatas sebanyak 18 orang responden atau $50 \%$.

\section{Deskriptif responden berdasarkan jenis kelamin}

Tabel 4.2

Karakteristik Responden Berdasarkan Jenis Kelamin

\begin{tabular}{|l|c|c|}
\hline Jenis Kelamin & $\begin{array}{c}\text { Jumlah Responden } \\
\text { (orang) }\end{array}$ & $\begin{array}{c}\text { Persentase } \\
\%\end{array}$ \\
\hline Laki-laki & 32 & 88,89 \\
\hline Perempuan & 4 & 11,11 \\
\hline Jumlah & 36 & 100 \\
\hline
\end{tabular}

Sumber: Hasil Penelitian (Data diolah, 2021)

Pada Tabel 4.2 dapat dilihat bahwa jenis kelamin laki-laki sebanyak 32 orang responden atau $88,89 \%$ dan jenis kelamin perempuan sebanyak 4 orang $11,11 \%$.

\section{Deskriptif responden berdasarkan pendidikan terakhir}

Tabel 4.3

Karakteristik Responden Berdasarkan Tingkat Pendidikan

\begin{tabular}{|l|c|c|}
\hline Tingkat Pendidikan & Jumlah Responden & Persentase \\
\hline SMP & 0 & 0 \\
\hline SLTA & 20 & 55,56 \\
\hline D3 & 2 & 5,55 \\
\hline S1 & 13 & 36,11 \\
\hline S2 & 1 & 2,78 \\
\hline Jumlah & 36 & 100 \\
\hline
\end{tabular}

Sumber: Hasil Penelitian (Data diolah, 2021) 
Pada Tabel 4.3 dapat dilihat bahwa tingkat pendidikan SMP sebanyak 0 responden atau $0 \%$, SLTA sebanyak 20 responden atau 55,56\%, D3 sebanyak 2 responden atau $5,55 \%$, S1 sebanyak 13 responden atau $36,11 \%$, S2 sebanyak 1 responden atau $\% 2,78$

\section{Analisis Deskriptif Variabel Penelitian}

Analisis deskriptif merupakan gambaran yang jelas mengenai jawaban atas pertanyaan/pernyataan atas variabel penelitian. Analisis deskriptif dilakukan peneliti yaitu dengan mendistribusikan jawaban responden dalam bentu tabel sehingga memperoleh gambaran yang jelas tentang distribusi jawaban responden. Adapun hasil dari analisis deskriptif untuk masing-masing pernyataan pada masing-masing variabel penelitian adalah sebagai berikut :

\section{Deskriptif Variabel Budaya Organisasi}

Distribusi jawaban responden terhadap 10 butir pernyataan mengenai variabel budaya organisasi $\left(\mathrm{X}_{1}\right)$ dapat dilihat padaTabel 4.4

Distribusi Jawaban Responden terhadap Variabel Budaya Organisasi (X1)

Tabel4.4

Distribusi Jawaban Responden Tentang Budaya Organisasi (X1)

\begin{tabular}{|c|c|c|c|c|c|c|c|c|c|c|c|c|}
\hline \multirow{2}{*}{ Pernyataan } & \multicolumn{2}{|c|}{ STS } & \multicolumn{2}{|c|}{ TS } & \multicolumn{2}{|c|}{ KS } & \multicolumn{2}{|c|}{$\mathrm{S}$} & \multicolumn{2}{|c|}{ SS } & \multirow[t]{2}{*}{ Total } & \multirow{2}{*}{$\%$} \\
\hline & $F$ & $\%$ & F & $\%$ & $\mathrm{~F}$ & $\%$ & $\mathrm{~F}$ & $\%$ & $\mathrm{~F}$ & $\%$ & & \\
\hline 1 & 0 & 0 & 0 & 0 & 4 & 11,1 & 22 & 61,1 & 10 & 27,8 & 36 & 100 \\
\hline 2 & 0 & 0 & 1 & 2,8 & 9 & 25 & 19 & 52,8 & 7 & 19,4 & 36 & 100 \\
\hline 3 & 0 & 0 & 0 & 0 & 7 & 19,4 & 16 & 44,4 & 13 & 36,1 & 36 & 100 \\
\hline 4 & 0 & 0 & 0 & 0 & 7 & 19,4 & 14 & 38,9 & 15 & 41,7 & 36 & 100 \\
\hline 5 & 0 & 0 & 0 & 0 & 4 & 11,1 & 22 & 61,1 & 10 & 27,8 & 36 & 100 \\
\hline 6 & 0 & 0 & 1 & 2,8 & 9 & 25 & 19 & 52,8 & 7 & 19,4 & 36 & 100 \\
\hline 7 & 0 & 0 & 1 & 2,8 & 7 & 19,4 & 14 & 38,9 & 14 & 38,9 & 36 & 100 \\
\hline 8 & 0 & 0 & 0 & 0 & 4 & 11,1 & 24 & 66,7 & 8 & 22,2 & 36 & 100 \\
\hline 9 & 0 & 0 & 0 & 0 & 4 & 11,1 & 22 & 61,1 & 10 & 27,8 & 36 & 100 \\
\hline 10 & 0 & 0 & 1 & 2,8 & 9 & 25 & 19 & 52,8 & 7 & 19,4 & 36 & 100 \\
\hline
\end{tabular}

Sumber: Kuesioner Penelitian, 2021 (diolah)

BerdasarkanTabel4.3distribusi jawaban responden tentang variabel Budaya Organisasi dapat dijelaskan sebagai berikut:

a. Untuk pernyataaan pertama"saya melaksanakan pekerjaan yang menjadi tugas, dilakukan dengan penuh kesadaran diri tanpa perintah pimpinan" dari 36 orang responden menjawab kurang setuju (KS)sebanyak4 orangresponden $(11,1 \%)$, menjawab setuju (S) sebanyak22 orangresponden $(61,1 \%)$, menjawab sangat setuju (SS) sebanyak 10 orangresponden $(27,8 \%)$.

b. Untuk pernyataaan kedua "dalam mengerjakan tugas yang menjadi tanggung jawab saya dikerjakan tanpa menunda-nunda" dari 36 orang responden menjawab tidak setuju (TS) sebanyak1 orangresponden $(2,8 \%)$, menjawab kurang setuju
(KS)sebanyak9 orangresponden (25\%), menjawab setuju (S) sebanyak19 orangresponden $(52,8 \%)$, menjawab sangat setuju (SS) sebanyak7 orangresponden $(19,4 \%)$.

c. Untuk pernyataaan ketiga "saya tidak akan merasa puas dengan satu tugas, sehingga saya tertantang dengan tugas yang berikutnya" dari 36 orang responden menjawab kurang setuju (KS)sebanyak7 orangresponden $(19,4 \%)$ menjawab setuju (S) sebanyak16 orangresponden $(44,4 \%)$, menjawab sangat setuju (SS) sebanyak13 orangresponden $(36,1 \%)$.

d. Untuk pernyataaan keempat"saya akan mengerjakan tugas lain setelah tugas yang sedangkan dikerjakan selesai" dari 36 orang responden menjawab kurang setuju (KS)sebanyak7 orangresponden $(19,4 \%)$, menjawab 
setuju (S) sebanyak14 orangresponden $(38,9 \%)$, menjawab sangat setuju (SS) sebanyak15 orangresponden $(41,7 \%)$.

e. Untuk pernyataaan kelima "saya mempunyai kepribadian yang luwes sehingga mudah untuk bergaul sesame rekan kerja" dari 36 orang responden menjawab kurang setuju (KS)sebanyak4 orangresponden $(11,1 \%)$, menjawab setuju (S) sebanyak22 orangresponden $(61,1 \%)$, menjawab sangat setuju sebanyak1 0 orangresponden $(27,8 \%)$.

f. Untuk pernyataaan keenam"saya mempunyai kepribadian yang luwes sehingga mudah untuk bergaul sesame rekan kerja" dari 36 orang responden menjawab tidak setuju (TS) sebanyak1 orangresponden $(2,8 \%)$, menjawab kurang setuju (KS)sebanyak9 orangresponden (25\%), menjawab setuju (S) sebanyak19 orangresponden $(52,8 \%)$, menjawab sangat setuju (SS) sebanyak 7 orangresponden $(19,4 \%)$.

g. Untuk pernyataaan ketujuh"setiap tugas yang diberikan pimpinan dapat saya diselesaikan tepat waktu" dari 36 orang responden menjawab tidak setuju (TS) sebanyak1 orangresponden $(2,8 \%)$, menjawab $\begin{array}{lll}\text { kurang } & \text { setuju (KS)sebanyak7 }\end{array}$ orangresponden (19,4\%), menjawab setuju (S) sebanyak14 orangresponden (38,9\%), menjawab sangat setuju (SS) sebanyak14 orangresponden $(38,9 \%)$.

h. Untuk pernyataaan kedelapan "saya dapat mengerjakan semua pekerjaan yang ditugaskan kepada saya dengan hasil yang memuaskan" dari 36 orang responden menjawab kurang setuju (KS)sebanyak4 orangresponden $(11,1 \%)$, menjawab setuju (S) sebanyak24 orangresponden $(66,7 \%)$, menjawab sangat setuju (SS) sebanyak 8 orangresponden $(22,2 \%)$.

i. Untuk pernyataaan kesembilan "saya akan mengerjakan tugas dari perusahaan dengan berkoordinasi sesama rekan kerja satu tim" dari 36 orang responden menjawab kurang setuju (KS)sebanyak4 orangresponden $(11,1 \%)$, menjawab setuju (S) sebanyak22 orangresponden $(61,1 \%)$, menjawab sangat setuju (SS) sebanyak1 0 orangresponden $(27,8 \%)$.

i. Untuk pernyataaan kesepuluh"sebelum melaksanakan pekerjaan yang menjadi bagian dari tim kerja, terlebih dahulu saya musyawarahkan" dari 36 orang responden menjawab tidak setuju (TS) sebanyak1 orangresponden $(2,8 \%)$, menjawab kurang setuju (KS)sebanyak9 orangresponden (25\%), menjawab setuju (S) sebanyak19 orangresponden $(52,8 \%)$, menjawab sangat setuju (SS) sebanyak7 orangresponden $(19,4 \%)$.

\section{Distribusi JawabanRespondenterhadapVariabel Lingkungan Kerja (X2)}

Tabel4.4

DistribusiJawabanRespondenTentang Lingkungan Kerja (X2)

\begin{tabular}{|c|c|c|c|c|c|c|c|c|c|c|c|c|}
\hline \multirow{2}{*}{ Pernyataan } & \multicolumn{2}{|c|}{ STS } & \multicolumn{2}{|c|}{ TS } & \multicolumn{2}{|c|}{ KS } & \multicolumn{2}{|c|}{$\mathrm{S}$} & \multicolumn{2}{|c|}{ SS } & \multirow[t]{2}{*}{ Total } & \multirow{2}{*}{$\%$} \\
\hline & $\mathrm{F}$ & $\%$ & $\mathrm{~F}$ & $\%$ & $F$ & $\%$ & $F$ & $\%$ & $\mathrm{~F}$ & $\%$ & & \\
\hline 1 & 0 & 0 & 0 & 0 & 10 & 27,8 & 20 & 55,6 & 6 & 16,7 & 36 & 100 \\
\hline 2 & 0 & 0 & 0 & 0 & 8 & 22,2 & 24 & 66,7 & 4 & 11,1 & 36 & 100 \\
\hline 3 & 0 & 0 & 1 & 2,8 & 9 & 25 & 19 & 52,8 & 7 & 19,4 & 36 & 100 \\
\hline 4 & 0 & 0 & 0 & 0 & 9 & 16,7 & 23 & 63,9 & 7 & 19,4 & 36 & 100 \\
\hline 5 & 0 & 0 & 0 & 0 & 6 & 16,7 & 23 & 63,9 & 7 & 19,4 & 36 & 100 \\
\hline 6 & 0 & 0 & 0 & 0 & 4 & 11,1 & 22 & 61,1 & 10 & 27,8 & 36 & 100 \\
\hline 7 & 0 & 0 & 1 & 2,8 & 9 & 25 & 19 & 52,8 & 7 & 19,4 & 36 & 100 \\
\hline 8 & 0 & 0 & 0 & 0 & 8 & 22,2 & 24 & 66,7 & 4 & 11,1 & 36 & 100 \\
\hline 9 & 0 & 0 & 1 & 2,8 & 9 & 25 & 19 & 52,8 & 7 & 19,4 & 36 & 100 \\
\hline 10 & 0 & 0 & 1 & 2,8 & 10 & 27,8 & 20 & 55,6 & 5 & 13,9 & 36 & 100 \\
\hline 11 & 0 & 0 & 0 & 0 & 10 & 27,8 & 20 & 55,6 & 6 & 16,7 & 36 & 100 \\
\hline 12 & 0 & 0 & 0 & 0 & 6 & 16,7 & 21 & 68,3 & 9 & 25 & 36 & 100 \\
\hline
\end{tabular}




\begin{tabular}{|l|l|l|l|c|c|c|c|c|c|c|c|c|}
\hline 13 & 0 & 0 & 0 & 0 & 5 & 13,9 & 25 & 69,4 & 6 & 16,7 & 36 & 100 \\
\hline 14 & 0 & 0 & 1 & 2,8 & 10 & 27,8 & 19 & 52,8 & 6 & 16,7 & 36 & 100 \\
\hline
\end{tabular}

Sumber: Kuesioner Penelitian, 2019 (diolah)

BerdasarkanTabe14.4distribusijaw abanrespondententang variabellingkungan kerja dapat dijelaskansebagaiberikut:

a. Untuk pernyataaan pertama "ruangan pekerjaan saya tertata rapi / dengan dekorasi pewarnaan yang cerah" dari 36 orang responden menjawab kurang setuju

(KS)sebanyak10 orangresponden $(27,8 \%)$, menjawab setuju (S) sebanyak20 orangresponden $(55,6 \%)$, menjawab sangat setuju (SS) sebanyak6 orangresponden $(16,7 \%)$.

b. Untuk pernyataaan kedua"pewarnaan yang cerah dapat memberikan kenyamanan saya dalam bekerja" dari 36 orang responden menjawab kurang setuju (KS)sebanyak8 orangresponden $(22,2 \%)$, menjawab setuju (S) sebanyak24 orangresponden $(66,7 \%)$, menjawab sangat setuju (SS) sebanyak 4 orangresponden $(11,1 \%)$.

c. Untuk pernyataaan ketiga"pencahayaan di tempat kerja saya tidak menyilaukan mata" dari 36 orang responden menjawab tidak setuju (TS) sebanyak1 orangresponden $(2,8 \%)$, menjawab kurang setuju (KS)sebanyak9 orangresponden (25\%), menjawab setuju (S) sebanyak19 orangresponden $(52,8 \%)$, menjawab sangat setuju (SS) sebanyak7 orangresponden $(19,4 \%)$.

d. Untuk pernyataaan keempat"penerangan di tempat kerja saya cukup baik" dari 36 orang responden menjawab kurang setuju (KS)sebanyak9 orangresponden $(16,7 \%)$, menjawab setuju (S) sebanyak23 orangresponden $(63,9 \%)$, menjawab sangat setuju (SS) sebanyak7 orangresponden $(19,4 \%)$.

e. Untuk pernyataaan kelima "sirkulasiudaraditempatkerjamembuats ayabernafas dengan oksigen yang cukup" dari 36 orang responden menjawab kurang setuju (KS)sebanyak6 orangresponden $(16,7 \%)$ menjawab setuju (S) sebanyak23 orangresponden $(63,9 \%)$, menjawab sangat setuju (SS) sebanyak7 orangresponden $(19,4 \%)$.

f. Untuk pernyataaan keenam"ventilasi udara ditempat kerja cukup baik" "' dari 36 orang responden menjawab kurang setuju (KS)sebanyak4 orangresponden $(11,1 \%)$, menjawab setuju (S) sebanyak22 orangresponden $(61,1 \%)$, menjawab sangat setuju (SS) sebanyak10 orangresponden $(27,8 \%)$.

g. Untuk pernyataaan ketujuh"saya dapat berkonsentrasidengan baik karena jauh dari kebisingan" dari 36 orang responden menjawab tidak setuju (TS) sebanyak1 orangresponden $(2,9 \%)$, menjawab kurang setuju (KS)sebanyak9 orangresponden (25\%), menjawab setuju (S) sebanyak19 orangresponden $(52,8 \%)$, menjawab sangat setuju (SS) sebanyak 7 orangresponden $(19,4 \%)$.

h. Untuk pernyataaan kedelapan "suasana tempat saya bekerja tenang karena jauh dari kebisingan" dari 36 orang responden menjawab kurang setuju (KS)sebanyak8 orangresponden $(22,2 \%)$, menjawab setuju (S) sebanyak24 orangresponden $(66,7 \%)$, menjawab sangat setuju (SS) sebanyak 4 orangresponden $(11,1 \%)$.

i. Untuk pernyataaan kesembilan "saya merasa mempunyai tanggung jawab terhadap pekerjaan yang dibebankan kepada saya"' dari 36 orang responden menjawab tidak setuju (TS) sebanyak1 orangresponden $(2,8 \%)$, menjawab kurang setuju (KS)sebanyak10 orangresponden $(27,8 \%)$, menjawab setuju (S) sebanyak19 orangresponden $(52,8 \%)$, menjawab sangat setuju (SS) sebanyak 7 orangresponden (19,4\%).

j. Untuk pernyataaan kesepuluh"setiap pekerjaan yang diberikan kepada saya dapat dipertangungjawabkan dengan baik" dari 36 orang responden menjawab tidak setuju (TS) sebanyak1 orangresponden $(2,8 \%)$, 
menjawab kurang setuju (KS)sebanyak10 orangresponden $(27,8 \%)$, menjawab setuju (S) sebanyak20 orangresponden $(52,8 \%)$, menjawab sangat setuju (SS) sebanyak5 orangresponden $(13,9 \%)$.

k. Untuk pernyataaan kesebelas "pimpinan selalu memberi dukungan kepada saya untuk pengembangan karir "" dari 36 orang responden menjawab kurang setuju (KS)sebanyak10 orangresponden $(27,8 \%)$, menjawab setuju (S) sebanyak20 orangresponden $(55,6 \%)$, menjawab sangat setuju (SS) sebanyak6 orangresponden $(16,7 \%)$.

1. Untuk pernyataaan keduabelas "saya selalu mendapat dukungan dari Pimpinan untuk memajukan perusahaan"" dari 36 orang responden menjawab kurang setuju (KS)sebanyak6 orangresponden $(16,7 \%)$ menjawab setuju (S) sebanyak2 1 orangresponden $(68,3 \%)$, menjawab sangat setuju (SS) sebanyak9 orangresponden $(25 \%)$.

m. Untuk pernyataaan ketigabelas"saya selalu berpartisipasi dalam kegiatan kelompok/tim untuk menyelesaikan pekerjaan besama-sama"' dari 36 orang responden menjawab kurang setuju (KS)sebanyak5 orangresponden $(13,9 \%)$, menjawab setuju (S) sebanyak25 orangresponden $(69,4 \%)$, menjawab sangat setuju sebanyak6 orangresponden $(16,7 \%)$.

n. Untuk pernyataaan keempatbelas "hubungan komunikasi antara saya dengan pimpinan terjalin baik"' dari 36 orang responden menjawab tidak setuju (TS) sebanyak1 orangresponden $(2,8 \%)$, menjawab kurang setuju (KS)sebanyak10 orangresponden $(27,8 \%)$, menjawab setuju (S) sebanyak19 orangresponden $(52,8 \%)$, menjawab sangat setuju (SS) sebanyak6 orangresponden

$(16,7 \%)$.

Tabel4.6

Distribusi Penilaian Terhadap Karyawan Oleh Pimpinan Pada Variabel Kinerja (Y)

\begin{tabular}{|c|c|c|c|c|c|c|c|c|c|c|c|c|}
\hline \multirow[b]{2}{*}{ Pernyataan } & \multicolumn{2}{|c|}{ STS } & \multicolumn{2}{|c|}{ TS } & \multicolumn{2}{|c|}{ KS } & \multicolumn{2}{|c|}{ S } & \multicolumn{2}{|c|}{ SS } & \multirow[t]{2}{*}{ Total } & \multirow{2}{*}{$\%$} \\
\hline & $\mathrm{F}$ & $\%$ & $\mathrm{~F}$ & $\%$ & $F$ & $\%$ & $\mathrm{~F}$ & $\%$ & $\mathrm{~F}$ & $\%$ & & \\
\hline 1 & 0 & 0 & 4 & 11,1 & 9 & 25 & 21 & 58,3 & 2 & 5,6 & 36 & 100 \\
\hline 2 & 0 & 0 & 2 & 5,6 & 9 & 25 & 22 & 61,1 & 3 & 8,3 & 36 & 100 \\
\hline 3 & 0 & 0 & 0 & 0 & 8 & 22,2 & 20 & 55,6 & 8 & 22,2 & 36 & 100 \\
\hline 4 & 0 & 0 & 0 & 0 & 8 & 22,2 & 17 & 47,2 & 11 & 30,6 & 36 & 100 \\
\hline 5 & 0 & 0 & 2 & 5,6 & 5 & 13,9 & 26 & 72,2 & 3 & 8,3 & 36 & 100 \\
\hline 6 & 0 & 0 & 1 & 2,8 & 9 & 25 & 21 & 58,3 & 5 & 13,9 & 36 & 100 \\
\hline 7 & 0 & 0 & 0 & 0 & 7 & 19,4 & 19 & 52,8 & 10 & 27,8 & 36 & 100 \\
\hline 8 & 0 & 0 & 0 & 0 & 4 & 11,1 & 22 & 61,1 & 10 & 27,8 & 36 & 100 \\
\hline 9 & 0 & 0 & 1 & 2,8 & 9 & 25 & 19 & 52,8 & 7 & 19,4 & 36 & 100 \\
\hline 10 & 0 & 0 & 0 & 0 & 7 & 19,4 & 20 & 55,6 & 9 & 25 & 36 & 100 \\
\hline
\end{tabular}

Sumber: Kuesioner Penelitian, 2019 (diolah)

BerdasarkanTabel4.6 distribusi jawaban pimpinan penilaian terhadap 36 karyawan pada variabel kinerja dapat dijelaskan sebagai berikut:

a. Untuk jawaban pertama "hubungan komunikasi antara saya dengan pimpinan terjalin baik" pimpinan memberikan penilaian jawaban kepada 36 orang karyawan.
Memberikan penilaian jawaban tidak setuju (TS) kepada 4 orang karyawan (11,1\%), memberikan penilaian jawaban kurang setuju (KS)kepada 9 orang karyawan (25\%), memberikan penilaian jawaban setuju (S)kepada 21 orang karyawan $(58,2 \%)$, memberikan penilaian jawaban sangat setuju (SS)kepada 2 
orang karyawanpun. (5,6\%), Hal in dapat disimpulkan bahwa $(58,2 \%)$ pegawai PDAM Tirta Musi 2 Palembang, dalam hubungan komunikasi dengan pimpinan terjalin baik

b. Untuk jawaban kedua"Karyawan ini selalu bersungguh-sungguh dan teliti dalam menyelesaikan tugas yang diberikan" pimpinan memberikan penilaian jawaban kepada 36 orang karyawan. Memberikan penilaian jawaban tidak setuju (TS) kepada 2 orang karyawan $(5,6 \%)$, memberikan penilaian jawaban kurang setuju (KS)kepada 9 orang karyawan (25\%), memberikan penilaian jawaban setuju (S)kepada 22 orang karyawan $(61,1 \%)$ memberikan penilaian jawaban sangat setuju (SS)kepada 3 orang karyawanpun. $(8,3 \%)$, Hal in dapat disimpulkan bahwa (61,1\%) pegawai PDAM Tirta Musi 2 Palembang, selalu bersungguhsungguh dan teliti dalam menyelesaikan tugas yang diberikan

c. Untuk jawaban ketiga "karyawan ini tidak menunda-nunda dalam menyelesaikan tugasnya" pimpinan memberikan penilaian jawaban kepada 36 orang karyawan. Memberikan penilaian jawaban kurang setuju (KS)kepada 8 orang karyawan (22,2\%), memberikan penilaian jawaban setuju (S)kepada 20 orang karyawan (55,6\%), memberikan penilaian jawaban sangat setuju (SS)kepada 8 orang karyawanpun. (22,2\%), Hal in dapat disimpulkan bahwa $(55,6 \%)$ pegawai PDAM Tirta Musi 2 Palembang, tidak menunda-nunda dalam menyelesaikan tugasnya

d. Untuk jawaban keempat "karyawan ini selalu mampumengerjakan pekerjaannya tanpa bantuann orang lain““ pimpinan memberikan penilaian jawaban kepada 36 orang karyawan. Memberikan penilaian jawaban kurang setuju (KS)kepada 8 orang karyawan $(22,2 \%)$, memberikan penilaian jawaban setuju (S)kepada 17 orang karyawan (47,2\%), memberikan penilaian jawaban sangat setuju (SS)kepada 11 orang karyawanpun. (30,6\%), Hal in dapat disimpulkan bahwa (47\%) pegawai PDAM Tirta Musi 2 Palembang, ini selalu mampumengerjakan pekerjaannya tanpa bantuann orang lain

e. Untuk jawaban kelima "karyawan ini selalu dapat bertanggung jawab atas tugas yang dikerjakannya“"“ pimpinan memberikan penilaian jawaban kepada 36 orang karyawan. Memberikan penilaian jawaban tidak setuju (TS) kepada 2 orang karyawan $(5,6 \%)$, memberikan penilaian jawaban kurang setuju (KS)kepada 5 orang karyawan (13,9\%), memberikan penilaian jawaban setuju (S)kepada 26 orang karyawan (72,2\%), memberikan penilaian jawaban sangat setuju (SS)kepada 3 orang karyawanpun. $(8,3 \%)$, Hal in dapat disimpulkan bahwa $(72,2 \%)$ pegawai PDAM Tirta Musi 2 Palembang, selalu dapat bertanggung jawab atas tugas yang dikerjakannya

f. Untuk jawaban keenam "dalam mengerjakan tugasnya karyawan ini selalu dapat menyelesaikan dengan peruh rasa tanggung jawab " pimpinan memberikan penilaian jawaban kepada 36 orang karyawan. Memberikan penilaian jawaban tidak setuju (TS) kepada 1 orang karyawan (2,8\%), memberikan penilaian jawaban kurang setuju (KS)kepada 9 orang karyawan (25\%), memberikan penilaian jawaban setuju (S)kepada 21 orang karyawan $(58,3 \%)$, memberikan penilaian jawaban sangat setuju (SS)kepada 5 orang karyawanpun. $(13,9 \%)$, Hal in dapat disimpulkan bahwa (58,3\%) pegawai PDAM Tirta Musi 2 Palembang, dalam mengerjakan tugasnya selalu dapat menyelesaikan dengan peruh rasa tanggung jawab

g. Untuk jawaban ketujuh"karyawan ini dapat bekerja sama dengan rekan sekerjanya" pimpinan memberikan penilaian jawaban kepada 36 orang karyawan. Memberikan penilaian jawaban kurang setuju (KS)kepada 7 
orang karyawan $(17,9 \%)$, memberikan penilaian jawaban setuju (S)kepada 19 orang karyawan (52,8\%), memberikan penilaian jawaban sangat setuju (SS)kepada $10 \quad$ orang karyawanpun. (27,8\%), Hal in dapat disimpulkan bahwa 52,8(\%) pegawai PDAM Tirta Musi 2 Palembang, dapat bekerja sama dengan rekan sekerjanya

g. Untuk jawaban kedelapan "karyawan ini selalu membantu jika ada teman sekerjanya mengalami kesulitan dalam bekerja“ pimpinan memberikan penilaian jawaban kepada 36 orang karyawan. Memberikan penilaian jawaban kurang setuju (KS)kepada 4 orang karyawan $(11,1 \%)$, memberikan penilaian jawaban setuju (S)kepada 22 orang karyawan (61,1\%), memberikan penilaian jawaban sangat setuju (SS)kepada $\quad 10$ orang karyawanpun. (27,8\%), Hal in dapat disimpulkan bahwa $(61,1 \%)$ pegawai PDAM Tirta Musi 2 Palembang, selalu membantu jika ada teman sekerjanya mengalami kesulitan dalam bekerja

h. Untuk jawaban kesembilan "karyawan ini selalu mempunyai ide dalam menyelesaikan tugas yang diberikan kepadanya" pimpinan memberikan penilaian jawaban kepada 36 orang karyawan. Memberikan penilaian jawaban tidak setuju (TS) kepada 1 orang karyawan (2,8\%), memberikan penilaian jawaban kurang setuju (KS)kepada 9 orang karyawan (25\%), memberikan penilaian jawaban setuju (S)kepada 19 orang karyawan $(52,8 \%)$, memberikan penilaian jawaban sangat setuju (SS)kepada 7 orang karyawanpun. $(19,4 \%)$, Hal in dapat disimpulkan bahwa (52,8\%) pegawai PDAM Tirta Musi 2 Palembang, selalu mempunyai ide dalam menyelesaikan tugas yang diberikan kepadanya

i. Untuk jawaban kesepuluh "karyawan ini selalu memberikan inisiatif kepada sesama rekan kerja" pimpinan memberikan penilaian jawaban kepada 36 orang karyawan. Memberikan penilaian jawaban kurang setuju (KS)kepada 7 orang karyawan $\quad(19,4 \%)$, memberikan penilaian jawaban setuju (S)kepada 20 orang karyawan (55,6\%), memberikan penilaian jawaban sangat setuju (SS)kepada 9 orang karyawanpun. (25\%), Hal in dapat disimpulkan bahwa $(55,6 \%)$ pegawai PDAM Tirta Musi 2 Palembang, dalam selalu memberikan inisiatif kepada sesama rekan kerja.

\section{Teknik Analisis Data \\ 1. Uji Instrumen Data \\ a. Uji Validasi}

MenurutSugiyono

(2012:109),validitas adalah suatu ukuran yang menunjukkan kevalidan atau kesahihan suatu instrumen. Valid berarti instrumen tersebut dapat digunakan untuk mengukur apa yang seharusnya diukur. Pengukuran dikatakan valid jika mengukur tujuannya dengan nyata dan benar. Pengujian validitas dari penelitian ini dilakukan dengan menggunakan aplikasi software SPSS Ver 24,0, jika otal ( Corrected Item Total Corelation) $=0,3$ jadi apabila $\mathrm{r}$ positif $>0,3$ maka item valid, sedangkan $\mathrm{r}$ negative $<0,3$ maka item tidak valid.

Tabel 4.6

Hasil Uji Validitas Variabel Budaya Organisasi (X1)

\begin{tabular}{|c|l|c|c|c|}
\hline No. & Pernyataan & $\mathrm{R}_{\text {hitung }}$ & $\mathrm{R}_{\text {tabel }}$ & Ket. \\
\hline 1 & $\begin{array}{l}\text { Saya melaksanakan pekerjaan yang menjadi } \\
\text { tugas, dilakukan dengan penuh kesadaran diri } \\
\text { tanpa perintah pimpinan }\end{array}$ & 0.691 & 0,30 & Valid \\
\hline 2 & $\begin{array}{l}\text { Dalam mengerjakan tugas yang menjadi } \\
\text { tanggung jawab saya dikerjakan tanpa } \\
\text { menunda-nunda }\end{array}$ & 0.790 & 0,30 & Valid \\
\hline 3 & $\begin{array}{l}\text { Saya tidak akan merasa puas dengan satu } \\
\text { tugas, sehingga saya tertantang dengan tugas } \\
\text { yang berikutnya. }\end{array}$ & 0.796 & 0,30 & Valid \\
\hline
\end{tabular}




\begin{tabular}{|c|l|c|c|c|}
\hline 4 & $\begin{array}{l}\text { Saya akan mengerjakan tugas lain setelah } \\
\text { tugas yang sedangkan dikerjakan selesai. }\end{array}$ & 0.832 & 0,30 & Valid \\
\hline 5 & $\begin{array}{l}\text { Saya mempunyai kepribadian yang luwes } \\
\text { sehingga mudah untuk bergaul sesame rekan } \\
\text { kerja }\end{array}$ & 0.691 & 0,30 & Valid \\
\hline
\end{tabular}

\begin{tabular}{|c|l|c|c|c|}
\hline 6 & $\begin{array}{l}\text { Saya senang membantu rekan kerja yang } \\
\text { sedang mengalami kesulitan dalam } \\
\text { menyelesaikan pekerjaan. }\end{array}$ & 0.790 & 0,30 & Valid \\
\hline 7 & $\begin{array}{l}\text { Setiap tugas yang diberikan pimpinan } \\
\text { dapat saya diselesaikan tepat waktu. }\end{array}$ & 0.826 & 0,30 & Valid \\
\hline 8 & $\begin{array}{l}\text { Saya dapat mengerjakan semua pekerjaan } \\
\text { yang ditugaskan kepada saya dengan hasil } \\
\text { yang memuaskan }\end{array}$ & 0.702 & 0,30 & Valid \\
\hline 9 & $\begin{array}{l}\text { Saya akan mengerjakan tugas dari } \\
\text { perusahaan dengan berkoordinasi sesama } \\
\text { rekan kerja satu tim }\end{array}$ & 0.691 & 0,30 & Valid \\
\hline 10 & $\begin{array}{l}\text { Sebelum melaksanakan pekerjaan yang } \\
\text { menjadi bagian dari tim kerja, terlebih } \\
\text { dahulu saya musyawarahkan. }\end{array}$ & 0.790 & 0,30 & Valid \\
\hline & & & \\
\hline
\end{tabular}

\section{Sumber : Data primer diolah SPSS 24}

Berdasarkan Tabel 4.6 dapat dilihat hasil dari uji validitas terhadap pernyataanpernyataan pada variabel budaya organisasi menunjukkan $r_{\text {hitung }}>r_{\text {tabel}}$, yang artinya secara keseluruhan pernyataan-pernyaatan pada variabel budaya organisasi (variabel X1) dinyatakan valid dan memenuhi syarat sebagai tolak ukur

Tabel 4.7

Hasil Uji Validitas Variabel Lingkungan Kerja (X2)

\begin{tabular}{|c|c|c|c|c|}
\hline No. & Pernyataan & $\mathrm{R}_{\text {hitung }}$ & $\mathrm{R}_{\text {tabel }}$ & Ket. \\
\hline 1 & $\begin{array}{l}\text { Ruangan pekerjaan saya tertata rapi / dengan } \\
\text { dekorasi pewarnaan yang cerah }\end{array}$ & 0.563 & 0,30 & Valid \\
\hline 2 & $\begin{array}{l}\text { Pewarnaan yang cerah dapat memberikan } \\
\text { kenyamanan saya dalam bekerja }\end{array}$ & 0.602 & 0,30 & Valid \\
\hline 3 & $\begin{array}{l}\text { Pencahayaan di tempat kerja saya tidak } \\
\text { menyilaukan mata }\end{array}$ & 0.816 & 0,30 & Valid \\
\hline 4 & Penerangan di tempat kerja saya cukup baik & 0.705 & 0,30 & Valid \\
\hline 5 & $\begin{array}{l}\text { Sirkulasiudaraditempatkerjamembuatsayabernafas } \\
\text { dengan oksigen yang cukup. }\end{array}$ & 0.632 & 0,30 & Valid \\
\hline 6 & Ventilasi udara ditempat kerja cukup baik & 0.572 & 0,30 & Valid \\
\hline 7 & $\begin{array}{l}\text { Saya dapat berkonsentrasidengan baik karena jauh } \\
\text { dari kebisingan }\end{array}$ & 0.816 & 0,30 & Valid \\
\hline 8 & $\begin{array}{l}\text { Suasana tempat saya bekerja tenang karena } \\
\text { jauh dari kebisingan }\end{array}$ & 0.602 & 0,30 & Valid \\
\hline 9 & $\begin{array}{l}\text { Saya merasa mempunyai tanggung jawab } \\
\text { terhadap pekerjaan yang dibebankan kepada saya }\end{array}$ & 0.816 & 0,30 & Valid \\
\hline 10 & $\begin{array}{l}\text { Setiap pekerjaan yang diberikan kepada saya } \\
\text { dapat dipertangungjawabkan dengan baik }\end{array}$ & 0.802 & 0,30 & Valid \\
\hline 11 & $\begin{array}{l}\text { Pimpinan selalu memberi dukungan kepada saya } \\
\text { untuk pengembangan karir }\end{array}$ & 0.541 & 0,30 & Valid \\
\hline 12 & $\begin{array}{l}\text { Saya selalu mendapat dukungan dari Pimpinan } \\
\text { untuk memajukan perusahaan }\end{array}$ & 0.418 & 0,30 & Valid \\
\hline
\end{tabular}




\begin{tabular}{|c|l|c|c|c|}
\hline 13 & $\begin{array}{l}\text { Saya selalu berpartisipasi dalam kegiatan } \\
\text { kelompok/tim untuk menyelesaikan pekerjaan } \\
\text { besama-sama. }\end{array}$ & 0.627 & 0,30 & Valid \\
\hline 14 & $\begin{array}{l}\text { Hubungan komunikasi antara saya dengan } \\
\text { pimpinan terjalin baik. }\end{array}$ & 0.798 & 0,30 & Valid \\
\hline
\end{tabular}

Sumber : Data primer diolah SPSS 24

Berdasarkan Tabel 4.7 dapat dilihat hasil dari uji validitas terhadap pernyataanpernyataan pada variabel lingkungan kerja menunjukkan $r_{\text {hitung }}>r_{\text {tabel }}$, yang artinya secara keseluruhan pernyataan-pernyaatan pada variabel lingkungan kerja (variabel X2) dinyatakan valid dan memenuhi syarat sebagai tolak ukur

Tabel 4.8

Hasil Uji Validitas Variabel Kinerja (Y)

\begin{tabular}{|c|l|c|c|c|}
\hline No. & Pernyataan & $\mathrm{R}_{\text {hitung }}$ & $\mathrm{R}_{\text {tabel }}$ & Ket. \\
\hline 1 & $\begin{array}{l}\text { Karyawan ini dalam mengerjakan } \\
\text { tugasnya selalu dikerjakan dengan } \\
\text { cepat dan sesuai standar yang } \\
\text { tetapkan perusahaan }\end{array}$ & 0.680 & 0,30 & Valid \\
\hline 2 & $\begin{array}{l}\text { Karyawan ini selalu bersungguh- } \\
\text { sungguh dan teliti dalam menyelesaikan } \\
\text { tugas yang diberikan }\end{array}$ & 0.711 & 0,30 & Valid \\
\hline 3 & $\begin{array}{l}\text { Karyawan ini tidak menunda-nunda } \\
\text { dalam menyelesaikan tugasnya. }\end{array}$ & 0.791 & 0,30 & Valid \\
\hline 4 & $\begin{array}{l}\text { Karyawan ini selalu } \\
\text { mampumengerjakan pekerjaannya } \\
\text { tanpa bantuann orang lain }\end{array}$ & 0.789 & 0,30 & Valid \\
\hline 5 & $\begin{array}{l}\text { Karyawan ini selalu dapat bertanggung } \\
\text { jawab atas tugas yang dikerjakannya }\end{array}$ & 0.612 & 0,30 & Valid \\
\hline 6 & $\begin{array}{l}\text { Dalam mengerjakan tugasnya karyawan } \\
\text { ini selalu dapat menyelesaikan } \\
\text { dengan peruh rasa tanggung jawab }\end{array}$ & 0.837 & 0,30 & Valid \\
\hline 7 & $\begin{array}{l}\text { Karyawan ini dapat bekerja sama dengan } \\
\text { rekan sekerjanya }\end{array}$ & 0.833 & 0,30 & Valid \\
\hline 8 & $\begin{array}{l}\text { Karyawan ini selalu membantu jika ada } \\
\text { teman sekerjanya mengalami kesulitan } \\
\text { dalam bekerja. }\end{array}$ & 0.444 & 0,30 & Valid \\
\hline 9 & $\begin{array}{l}\text { Karyawan ini selalu mempunyai ide } \\
\text { dalam menyelesaikan tugas yang } \\
\text { diberikan kepadanya. }\end{array}$ & 0.807 & 0,30 & Valid \\
\hline 10 & $\begin{array}{l}\text { Karyawan ini selalu memberikan } \\
\text { inisiatif kepada sesama rekan kerja. }\end{array}$ & 0.876 & 0,30 & Valid \\
\hline
\end{tabular}

Sumber : Data primer diolah SPSS 24

Berdasarkan Tabel 4.8 dapat dilihat hasil dari uji validitas terhadap pernyataanpernyataan pada variabel kinerja menunjukkan $r_{\text {hitung }}>r_{\text {tabel}}$, yang artinya secara keseluruhan pernyataan-pernyaatan pada variabel kinerja (variabel Y) dinyatakan valid dan memenuhi syarat sebagai tolak ukur 


\section{b. Reliabilitas}

Uji reliabilitas menurut Sugiyono(2015:109) Reliabilitas menunjukkan akurasi dan konsistensi dari pengukurannya. Dikatakan konsisten jika beberapa pengukuran terhadap subyek yang sama diperoleh hasil yang tidak berbeda.Reliabilitas menunjukkan tingkat kestabilan, konsistensi,dan atau kehandalan instrumen untuk menggambarkan gejala seperti apa adanya. Butir pertanyaan yangs udah dinyatakan valid dalam uji validitas akan ditentukan reliabilitasnya dengan kriteria jika Cronbach'sAlpha $>0,60$

- Realibilitas Variabel Budaya Organisasi $\left(\mathrm{X}_{1}\right)$

Hasil perhitungan nilai reliabilitas Cronbach Alpa untuk variabel budaya organisasi dengan bantuan SPSS 24, 0 adalah sebesar 0,941Artinya dari 10 item pernyataan yang dijadikan sebagai indikator pada variabel budaya organisasi (X1) sudah reliabel.

- Realibilitas Variabel Lingkungan Kerja (X2)

Hasil perhitungan nilai reliabilitas Cronbach Alpa untuk variabel lingkungan kerja dengan bantuan SPSS 24,0 adalah sebesar 0,929 Artinya dari 14 item pernyataan yang dijadikan sebagai indikator pada variabel lingkungan kerja (X2) sudah reliabel.
- Realibilitas Variabel Kinerja (Y)

Hasil perhitungan nilai reliabilitas Cronbach Alpa untuk variabel kinerja dengan bantuan SPSS 24,0 adalah sebesar 0,934 Artinya dari 10 item pernyataan yang dijadikan sebagai indikator pada variabel kinerja (Y) sudah reliabel.

Hasil uji realibilitas secara lebih terperinci dapat dilihat pada tabel berikut ini :

Tabel 4.9

Hasil Uji Reliabilitas

\begin{tabular}{|c|c|c|}
\hline Variabel & $\begin{array}{c}\text { Alpha } \\
\text { Cronbach } \\
(\alpha)\end{array}$ & Status \\
\hline Budaya Organisasi & 0,941 & Reliabel \\
\hline Lingkungan Kerja & 0,929 & Reliabel \\
\hline Kinerja & 0,934 & Reliabel \\
\hline
\end{tabular}

Sumber : Data primer diolah SPSS 24,

\section{Uji AsumsiKlasik}

Uji asumsi klasik ini dilakukan untuk mengetahui kondisi data yang adadalam penelitian ini dan menentukan model analisis yang paling tepat digunakan. Uji asumsi klasik yang digunakan dalam penelitian terdiridari:

\section{a. Uji Normalitas Data}

Uji normalitas bertujuan untuk menguji apakah model regresi memiliki distribusi data yang normal. Hasil analisis grafik dilihat melalui penyebaran pada sumbu diagona P-Plot atau dengan melihat grafik
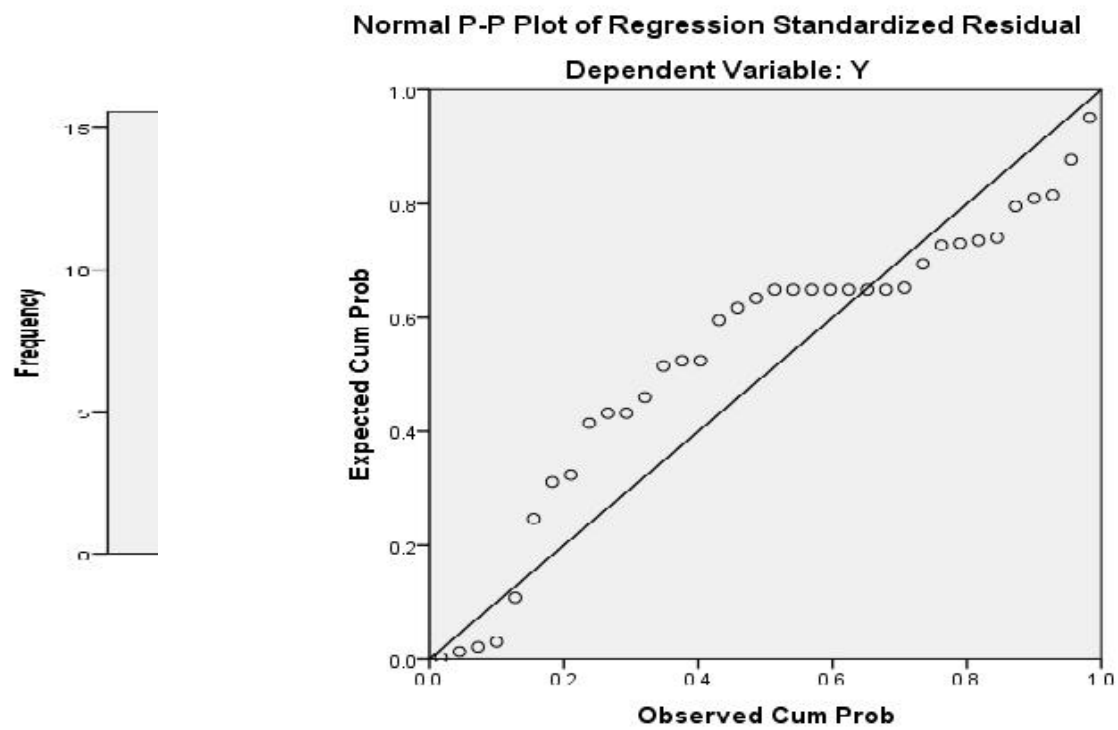


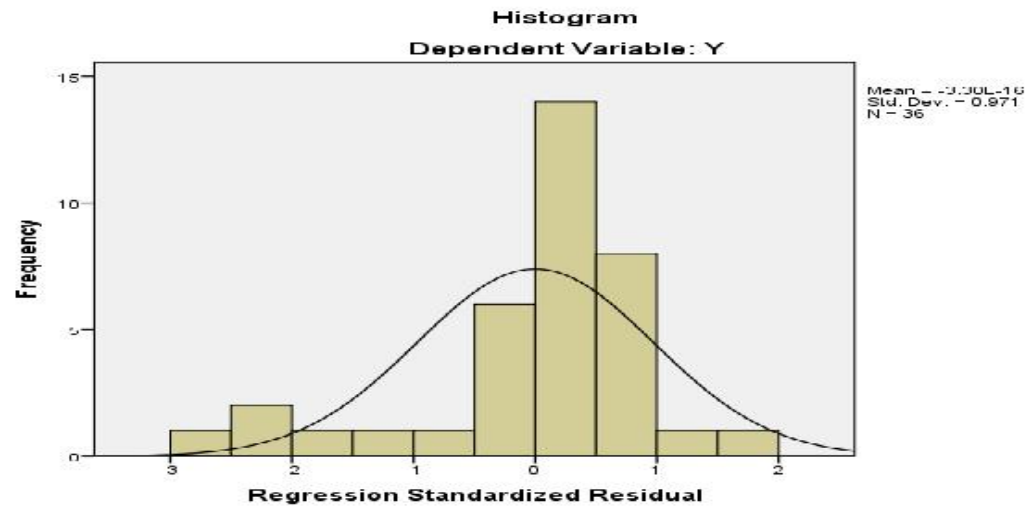

Dengan melihat tampilan grafik $p$ plot dapat diliha ttitik-titik yang menyebar disekitar garis diagonal,serta arah penyebarannya mengikuti arah garis diagonal.Grafik histogram diatas memberikan pola distribusi yang normal. Kedua grafik tersebut menunjukkan bahwa model regresi layak memenuhi asumsi normalitas.Untuk mendukung hasil uji grafik penulis juga melakukan uji normalitas dengan menggunakan uji statistik yaitu dengan One SampleKolmogorovSmirnovTest. DalamOne Sample Kolmogorov Smirnov Test suatu data akan berdistribusi secara normal jika memilikinilaiAsymp. Sig. (2-tailed)yang lebih besar dari0.05.

\section{b. Uji Multikolinieritas}

Pengujian ini bertujuan untuk menguji apakah model regresi ditemukan adanya korelasi antara variabel independen. Modelr egresi yang baik seharusnya tidak terjadi korelasi diantara variabel independen.Berikut hasil uji multikolinearitas terhadap model dalam penelitian ini.

Tabel 4.10

Hasil Uji Multikolinieritas

\begin{tabular}{|c|c|c|c|c|c|c|c|c|}
\hline \multicolumn{9}{|c|}{ Coefficients $^{\mathrm{a}}$} \\
\hline & & \multicolumn{2}{|c|}{$\begin{array}{l}\text { Unstandardized } \\
\text { Coefficients }\end{array}$} & \multirow{2}{*}{$\begin{array}{c}\begin{array}{c}\text { Standardize } \\
\mathrm{d} \\
\text { Coefficients }\end{array} \\
\text { Beta } \\
\end{array}$} & \multirow[b]{2}{*}{$\mathrm{t}$} & \multirow[b]{2}{*}{ Sig. } & \multicolumn{2}{|c|}{$\begin{array}{l}\text { Collinearity } \\
\text { Statistics }\end{array}$} \\
\hline \multicolumn{2}{|c|}{ Model } & B & Std. Error & & & & $\begin{array}{c}\text { Toleranc } \\
\mathrm{e}\end{array}$ & VIF \\
\hline 1 & (Constant & -2.360 & 2.532 & & -.932 & .358 & & \\
\hline & $\mathrm{X} 1$ & .419 & .126 & .431 & 3.318 & .002 & .182 & 5.505 \\
\hline & $\mathrm{X} 2$ & .445 & .107 & .541 & 4.167 & .000 & .182 & 5.505 \\
\hline
\end{tabular}

a. Dependent Variable: Y

Hasil uji multikolinearitas dari masing-masingvariabel independen menunjukan nilai Variance Inflation Factor (VIF) memiliki nilai tidak lebih dari10,begitu juga apabila ditinjau dari nilaiTolerance memiliki nilai tidak kurang dari0.1.Jadi dapat dikatakan bahwa masing-masing dari variabel independen terbebas dari multikolinearitas dalam mode lregresi ini 


\section{c. Uji Heteroskedastisitas}

Model regresi yang baik adalah yang homoskodesitas atau tidak terjadiheteroskedasitas. Uji inidilakukan dengan menggunakan analisis grafik scatterplot antara nilai prediksi variabel ZPRED denganresidualnyaSRESID.Untukmengetahui adanya heteroskedastisitas adalahdenganmelihatadatidaknyapolatertentu padagrafikScatterplotdengan ketentuan :

1. Jika terdapat pola tertentu,seperti titik-titikyang ada membentuk pola tertentu yang teratur mak amenunjukkan telah terjad igejala heteroskedastisitas.

2. Jika tidak ada pola yang jelas, sertat itik-titik menyebar diatas dan dibawah angka 0 pada sumbu Y,maka tidak terjadi heteroskedastisitas.

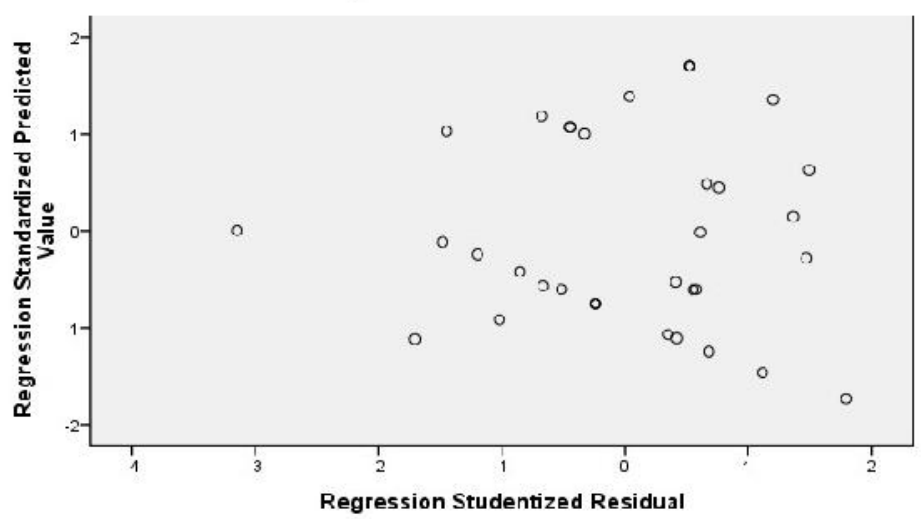

Dari grafik scatterplot terlihat bahwa titik-titik menyebar secara acak diatas maupun dibawah angka 0 pada sumbuY. Hal ini dapat disimpulkan bahwa tidak terjadi heteroskedasitas pada model regresi.

\section{Uji Regresi Berganda}

Data yang diperoleh dari responden dalam penelitian ini dianalisis dengan menggunakan model regresi linier berganda dengan tujuan untuk mengetahui besarnya kontribusi dari variabel-variabel bebas (independent) dalam penelitian ini, yaitu variabel budaya organisasi dan lingkungan kerja untuk memprediksi variabel kinerja (Y) sebagai variabel terikat (dependent), sehingga dapat dijelaskan pula mengenai variabel bebas yang paling berpengaruh terhadap variabel terikatnya. Pengolahan data dilakukan dengan menggunakan program SPSS 24,0 dengan hasil sebagaimana terlihat pada tabel berikut:

Tabel 4.11

Coefficients $^{\mathrm{a}}$

\begin{tabular}{|c|c|c|c|c|c|c|}
\hline \multicolumn{7}{|c|}{ Coefficients $^{\mathbf{a}}$} \\
\hline \multirow{2}{*}{\multicolumn{2}{|c|}{ Model }} & \multicolumn{2}{|c|}{ Unstandardized Coefficients } & \multirow{2}{*}{$\begin{array}{c}\begin{array}{c}\text { Standardized } \\
\text { Coefficients }\end{array} \\
\text { Beta }\end{array}$} & \multirow[b]{2}{*}{$\mathrm{t}$} & \multirow[b]{2}{*}{ Sig. } \\
\hline & & B & Std. Error & & & \\
\hline \multirow[t]{3}{*}{1} & (Constant) & -2.360 & 2.532 & & -.932 & .358 \\
\hline & $\mathrm{X} 1$ & .419 & .126 & .431 & 3.318 & .002 \\
\hline & $\mathrm{X} 2$ & .445 & .107 & .541 & 4.167 & .000 \\
\hline
\end{tabular}

a. Dependent Variable: Y

Dengan persamaan regresi :

$\mathrm{a}+\mathrm{b} 1 \mathrm{X} 1+\mathrm{b} 2 \mathrm{X} 2$

$\mathrm{Y}=-2,360+0,419 \mathrm{~b} 1+0,445 \mathrm{~b} 2$

Keterangan :

a. Konstanta $(a)=-2,360$. Artinya hal tersebut menunjukkan bahwa nilai konsisten variabel kinerja sebesar $-2,360$ 
b. Koefisien regresi $\left(b_{1}\right)=0,419$. Artinya bahwa setiap penambahan $1 \%$ nilai variabel budaya organisasi maka nilai variabel kinerja akan bertambah sebesar 0,419

c. Koefisien regresi $\left(b_{2}\right)=0,445$. Artinya bahwa setiap penambahan $1 \%$ nilai variabel lingkungan kerja maka nilai variabel kinerja akan bertambah sebesar 0,445

\section{Uji Koefisien Korelasi (r) dan Determinasi $\left(\mathbf{R}^{2}\right)$}

Fungsi dari analisi skor korelasi adalah untuk menentukan seberapa erat hubungan antara satu variabel dengan variabel lainnya. Sedangkan koefisien determinasi $\left(\mathrm{R}^{2}\right)$ digunakan untuk mengukur seberapa jauh kemampuan model dalam menerangkan variasi variabel dependen (Sanusi, 2016:86). Adapun interpretasi koefisien korelasi adalah sebagai berikut :

Tabel 4.11

Interpretasi Koefisien Korelasi

\begin{tabular}{|c|c|}
\hline Interval Koefisien & Tingkat Hubungan \\
\hline $0,000-0,199$ & SangatLemah \\
\hline $0,200-0,399$ & Lemah \\
\hline $0,400-0,599$ & Cukup \\
\hline $0,600-0,799$ & Kuat \\
\hline $0,800-0,1000$ & SangatKuat \\
\hline
\end{tabular}

Sumber : Sugiyono (2015:126).

Adapun hasil pengujian koefisien korelasi dan determinasi antara budaya organisasi dan lingkungan kerja terhadap kinerja pada tabel dibawah ini :

Tabel 4.11

Hasil Uji Koefisien Korelasi dan Determinasi

\begin{tabular}{|c|c|c|c|c|}
\hline \multicolumn{5}{|c|}{ Model Summary } \\
\hline Model & R & R Square & Adjusted R Square & Std. Error of the Estimate \\
\hline 1 & $.948^{\mathrm{a}}$ & .899 & .893 & 1.80649 \\
\hline \multicolumn{5}{|c|}{ a. Predictors: (Constant), X2, X1 } \\
\hline
\end{tabular}

Berdasarkan Tabel 4.11 diketahui nilai r (koefisien korelasi) sebesar 0,948 yang artinya nilai variabel budaya organisasi dan lingkungan kerja memiliki hubungan yang kuat terhadap variabel kinerja

Untuk koefisien determinasi $\left(\mathrm{R}^{2}\right)$ diketahui sebesar 0,899 yang artinya menunjukkan kinerja karyawan (Y) dalam menerangkan budaya organisasi (X1) lingkungan kerja (X2) sebesar $89,8 \%$ dan sisanya $10,1 \%$ dijelaskan oleh variabel yang lain yang tidak di teliti dalam penelitian ini.

\section{Uji Hipotesis}

a. Uji $T$

UjiParsial(Uji-t)digunakanuntukmengetahui pengaruhvariabel budaya organisasi dan lingkungan kerja secaraparsialterhadapvariabelkinerja.

Hasilpengujianadalah :

Tingkatkesalahan $(\alpha)=5 \%$ danderajatkebebasan $(\mathrm{df})=(\mathrm{n}-\mathrm{k})=36-3=33$ 
Tabel4.12

Hasil Uji Parsial(Ujit)

\begin{tabular}{|c|c|c|c|c|c|c|}
\hline \multicolumn{7}{|c|}{ Coefficients $^{\mathrm{a}}$} \\
\hline \multirow{2}{*}{\multicolumn{2}{|c|}{ Model }} & \multicolumn{2}{|c|}{$\begin{array}{l}\text { Unstandardized } \\
\text { Coefficients }\end{array}$} & \multirow{2}{*}{$\begin{array}{c}\text { Standardized } \\
\text { Coefficients } \\
\text { Beta }\end{array}$} & \multirow[b]{2}{*}{$\mathrm{t}$} & \multirow[b]{2}{*}{ Sig. } \\
\hline & & B & Std. Error & & & \\
\hline \multirow[t]{3}{*}{1} & (Constant) & -2.360 & 2.532 & & -.932 & .358 \\
\hline & $\mathrm{X} 1$ & .419 & .126 & .431 & 3.318 & .002 \\
\hline & $\mathrm{X} 2$ & .445 & .107 & .541 & 4.167 & .000 \\
\hline
\end{tabular}

a. Dependent Variable: Y

Berdasarkan Tabel 4.12 hasil pengujian secara parsial (Uji-t) pengaruh masing-masing variabel independen terhadap variabel dependen dengan taraf nyata5\% $(0,05)$ pada $\mathrm{df}=33$ diperoleh nilai $\mathrm{t}$ tabel sebesar 2,035 Maka kriteria pengambilan keputusan adalah sebagaiberikut:

- Pengujian Variabel Budaya Organisasi Variabel budaya organisasi berpengaruh positif dan signifikan secara parsial terhadapkinerja, haliniterlihatdarinilai $\mathrm{t}$ hitung $(3,318)>$ t-tabel $(2,035)$.

Kriteria pengambilan keputusan :

$\mathrm{H}_{\mathrm{o}}=$ koefiesien regresi (budaya organisasi) secara parsial tidak berpengaruh terhadap kinerja

$\mathrm{H}_{1}=$ koefiesien regresi (budaya organisasi) secara parsial berpengaruh terhadap kinerja

Berdasarkan hasil pengujian diperoleh nilai t-hitung $(3,318>t$-tabel $(2,035)$. maka $\mathrm{H}_{0}$ ditolak, $\mathrm{H}_{1}$ diterima, artinya bahwa variabel budaya organisasi secara parsial berpengaruh terhadap kinerja

- Pengujian Variabel Lingkungan Kerja Variabel lingkungan kerjaberpengaruh positif dan signifikan secara parsial terhadapkinerja,haliniterlihatdarinilai thitung $(4,167)>$ t-tabel $(2,035)$.

Kriteria pengambilan keputusan : $\mathrm{H}_{\mathrm{o}}=$ koefiesien regresi (lingkungan kerja) secara parsial tidak berpengaruh terhadap kinerja

$\mathrm{H}_{1}=$ koefiesien regresi (lingkungan kerja) secara parsial berpengaruh terhadap kinerja Berdasarkan hasil pengujian diperoleh nilai t-hitung $(4,167)>t$-tabel $(2,035)$, maka $\mathrm{H}_{0}$ ditolak, $\mathrm{H}_{1}$ diterima, artinya bahwa variabel lingkungan kerjasecara parsial berpengaruh terhadap kinerja

\section{b. Uji $F$}

Uji Signifikasi Pengaruh

Simultan (Uji F)

Untuk menentukan nilai F-tabel, maka diperlukan adanya derajat bebas pembilang dan derajat bebas penyebut dengan rumus sebagai berikut:

df $($ Pembilang $)=k-1$ df $($ Penyebut $)=n-k$

Keterangan :

$\mathrm{n}=$ Jumlah sampel penelitian

$\mathrm{k}=$ Jumlah variabel bebas danterikat

Pada penelitian ini diketahui jumlah sampel (n) dan jumlah keseluruhan variabel (k) adalah 3.Sehingga diperoleh:

df $1=\mathrm{k}-1=3-1=2$

$\mathrm{df} 2=\mathrm{n}-\mathrm{k}=36-3=33$

Nilai F- hitung akan diperoleh dengan menggunakan bantuan SPSS, kemudian akan dibandingkan dengan $\mathrm{F}$ tabel pada tingkat

$\alpha=5 \%$.

Tabel4.13

HasilUji Simultan (UjiF)

\begin{tabular}{|l|l|r|r|r|r|r|}
\hline \multicolumn{7}{|c|}{ ANOVA $^{\text {a }}$} \\
\hline \multirow{2}{*}{ Model } & \multicolumn{1}{|c|}{$\begin{array}{c}\text { Sum of } \\
\text { Squares }\end{array}$} & df & Mean Square & F & \multicolumn{1}{c|}{ Sig. } \\
\hline \multirow{2}{*}{1} & Regression & 959.057 & 2 & 479.529 & 14.6941 & $.000^{\mathrm{b}}$ \\
\cline { 2 - 8 } & Residual & 107.693 & 33 & 3.263 & & \\
\cline { 2 - 8 } & Total & 1066.750 & 35 & & & \\
\hline
\end{tabular}


a. Dependent Variable: Y

b. Predictors: (Constant), X2, X1

Berdasarkan Tabel 4.13 terlihat bahwa nilai $\mathrm{F}$ - hitung adalah sebesar 14.6941 dengan tingkat singnifikasi 0,000 . Sedangkan F-tabel pada tingkat kepercayaan $5 \%(\alpha=0,05)$ dan derajat kebebasan pembilang $(\mathrm{df} 1)=2$ dan derajat penyebut $\left(\mathrm{df}_{2}\right)=33$ adalah sebesar 3,285. Maka terlihat bahwa nilai F- hitung (14.69)>F-tabel (3,285). Menunjukan bahwa variabel bebas secara serempak berpengaruh positif dan signifikan terhadap kinerja.

Kriteria pengambilan keputusan :

$\mathrm{H}_{0}: \mathrm{b}_{1}, \mathrm{~b}_{2} \neq 0$, artinya secara bersamasama tidak terdapat pengaruh yang positif dan signifikan dari variabel bebas $\left(\mathrm{X}_{1}, \mathrm{X}_{2}\right)$ yaitu berupa budaya organisasi dan lingkungan kerja terhadap kinerja karyawan sebagai variabel terikat $(\mathrm{Y})$.

$\mathrm{H}_{1}: \mathrm{b}_{1}, \mathrm{~b}_{2}=0$, artinya secara bersamasama terdapat pengaruh yang positif dan signifikan dari variabel bebas $\left(\mathrm{X}_{1}, \mathrm{X}_{2}\right)$ yaitu berupa yaitu berupa budaya organisasi dan lingkungan kerja terhadap kinerja karyawan

Berdasarkan hasil pengujian diperoleh nilai $\mathrm{F}$-hitung $(14,69)>\mathrm{F}$-tabel (3,285). maka $\mathrm{H}_{0}$ ditolak, $\mathrm{H}_{1}$ diterima, artinya bahwa variabel budaya organisasi dan lingkungan kerjasecara simultan berpengaruh terhadap kinerja

\section{KESIMPULAN DAN SARAN SARAN \\ 5.1 Kesimpulan}

1. Hasil penelitian menunjukkan bahwa secara parsial variabel budaya organisasi mempengaruhi kinerja pegawai PDAM Tirta Musi Unit Seberang Ulu 2 Palembang, pengujian hipotesis $\left(\mathrm{H}_{1}\right)$ telah membuktikan terdapat pengaruh budaya organisasi terhadap kinerja pegawai. Hasil perhitungan yang telah dilakukan diperoleh Nilai $\mathrm{t}$ hitung 3,318danttabel bernilai,sehingga(7,380 >2,035), sehingga disimpulkan bahwa variabel budaya organisasi berpengaruh positif dan signifikan terhadap kinerja.

2. Pada variabel lingkungan kerja secara parsial berpengaruh terhadap kinerja pegawai PDAM Tirta Musi Unit Seberang Ulu 2 Palembang, pengujian hipotesis $\left(\mathrm{H}_{2}\right)$ telah membuktikan terdapat pengaruh lingkungan kerja terhadap kinerja pegawai. Hasil perhitungan diperoleh nilai thitung 4,167 dan t tabel bernilai 2,035 , sehingga $(4,042>2,035)$, sehingga disimpulkan bahwa variabel lingkungan kerja berpengaruh positif dan signifikan terhadap kinerja.

3. Pada variabel budaya organisasi dan lingkungan kerja secara simultan berpengaruh terhadap pegawai PDAM Tirta Musi Unit Seberang Ulu 2 Palembang, pengujian hipotesis $\left(\mathrm{H}_{3}\right)$ telah membuktikan terdapat pengaruh budaya organisasi dan lingkungan kerja terhadap kinerja pegawai. Hasil perhitungan diperoleh nilai $\mathrm{F}$ hitung 14,69 dan $\mathrm{F}$ tabel bernilai 3,285 sehingga $F(14.69>3,285)$, sehingga disimpulkan bahwa variabel budaya organisasi dan lingkungan kerja berpengaruh secara simultan terhadap kinerja

\subsection{Saran-Saran}

1. Agar karyawan tetap menunjukan budaya organisasi yaitu loyalitas, tingkat partisipasi yang tinggi dan kesediaan untuk berusaha sebaik mungkin demi kepentingan perusahaan dalam meningkatkan prestasi kerja karyawan hendaknya perusahaan lebih memperhatikan dan memberikan kebebasandan kepercayaan penuh serta tanggung jawab kepada karyawan dalam menjalankan tugasnya.

2. Untuk membenahi lingkungan kerja, hendaknya pihak manajemen/ perusahan 
menata kembali tata ruang, tata tempat (layout) perlengkapan kantor maupun peralatan kantor sesuai dengan tempatnya sehingga tertata rapi.

3. Guna meningkatkan kinerja karyawan hendaknya perusahaan /manajemen memberikan kebebasan atau independensi kepada setiap karyawan dalam mengemukakan pendapat, inisiatif individu serta ide untuk memajukan dan mengembangkan organisasi atau perusahaan.

\section{DAFTAR PUSTAKA}

Ardana Mujiati, Manajemen Sumber Daya Manusia, Cetakan Ketiga, Graha Ilmu, Yogyakarta. 2015

Anwar Sanusi, Metode Penelitian Bisnis, Salemba Empat, Jakarta, 2016

Alex S. Nitisemito, Manajemen Personalia, Manajemen Sumber Daya Manusia, Ghalia, Jakarta, 2015

A.A Anwar Parabu Mangkunegara, , Manajemen Sumber Daya Manusia Perusahaan, PT. Remaja Rosda Karya, Bandung. 2016

Djokosantoso Moeljono, Budaya Organisasi Dalam Tantangan, PT Pustaka Binaman Pressindo, Jakarta, 2014

Edwin B. Flippo, Manajemen Personalia, Jilid 2, Erlangga, Jakarta, 2015

Edy Sutrisno, Manajemen Sumber Daya Manusia, Kencana, Jakarta, $2012 \backslash 5$

Fred Luthans, Perilaku Organisasi, Diterjemahkan oleh Vivin Andika, Yuwono, Edisi ke Pertama, Penerbit Andi, Yogyakarta, 2015

Fuad Mas'ud, Mitos Manajemen Sumber Daya Manusia, Badan Penerbit Universitas Diponegoro, Semarang, 2015

Joko Widagdho, Ilmu Budaya Dasar, Bumi Aksara, 2015

Djokosantoso, Budaya Korporat dan Keunggulan Korporat, PT. Elex Media Komputindo, Jakarta, 2015

Hadari Nawawi, Manajemen Sumber Daya Manusia, Gadjah Mada University Press, Yogyakarta, 2015

Hani Handoko, Manajemen Personalia \& Sumberdaya Manusia (Edisi 2),
BPFE. Yogyakarta, 2012

Komarudin, Manajemen Sumber Daya Manusia, Kuppa Sigma, Bandung, 2015

Malayu S.P Hasibuan, Manajemen Sumber Daya Manusia , Bumi Aksara, Jakarta, 2016

Moh. As'ad, Psikologi Industri, Seri Umum Sumber Daya Manusia, Edisi 4, Liberty, Yogyakarta, 2015

Sedarmayanti, Sumber Daya Manusia Dan Produktivitas Kerja, Mandar Maju, Bandung, 2015

Sarwoto, Efektivitas Riset Manajemen Sumber Daya Manusia, Gramedi Pustaka Utama, Jakarta, 2015

Soehardi Sigit. Esensi Perilaku Organisasi. Penerbit Lukman Offset, Yogyakarta, 2015

Puspowarsito, Metode Penelitian Organisasi Dengan Aplikasi Program SPSS, Humaniora, Bandung, 2008

Sugiyono, Metode Penelitian Bisnis, Alfabeta, Bandung, 2015

Sunarto, Perilaku Organisasi, Edisi Ketiga, Amus, Yogyakarta, 2015

Srimulyo, Manajemen Sumber Daya Manusia PT. Remaja Rosdakarya, Bandung, 2015

Surya Dharma, Manajemen Kinerja: Falsafah Teori dan Penerapannya, Pustaka Pelajar, Yogyakarta, 2015

Stephen Robbins dan Timothy A. Judge, Perilaku Organisasi. Salemba Empat. Jakarta, 2014

Veithzal Rivai Manajemen Sumber Daya Manusia Untuk Perusahaan, Edisi Kedua, Raja Grafindo, Jakarta, 2017

Wirawan, Budaya dan Iklim Organisasi, Teori Aplikasi dan Penelitian, Salemba Empat, Jakarta, 2016

Wilson Bangun, Manajemen Sumber Daya Manusia, Erlagga, Jakarta, 2015 